NBER WORKING PAPER SERIES

\begin{abstract}
INTERNATIONAL INTEREST-RATE AND PRICE-LEVEL LINKAGES UNDER FLEXIBLE EXCHANGE RATES:

A REVIEW OF RECENT EVIDENCE
\end{abstract}

\author{
Robert E. Cumby \\ Maurice Obstfeld \\ Working Paper No. 921 \\ NATIONAL BUREAU OF ECONOMIC RESEARCH \\ 1050 Massachusetts Avenue \\ Cambridge MA 02138 \\ June 1982
}

The research reported here is part of the NBER's research program in International Studies. Any opinions expressed are those of the authors and not those of the National Bureau of Economic Research. 


\section{International Interest-Rate and Price-Level Linkages under Flexible Exchange Rates: A Review of Recent Evidence}

\section{Abstract}

In an open economy, the scope for activist stabilization policy depends on the nature of the linkages between domestic and international markets for goods and assets. Two important relationships--purchasing power parity and uncovered interest-rate parity--have received extensive empirical attention in recent years and are fundamental building blocks of several empirical exchange rate models. This paper reviews and extends recent econometric findings on these two classical parity relationships and on their corollary, the international equality of expected real interest rates.

Econometric tests assuming rationality of expectations are on the whole unfavorable to the classical parity relationships: with few exceptions, they are strongly rejected. A central theme in the review of empirical work is the conditional heteroskedasticity of inflation and exchange rate forecast errors and the bias this statistical problem may impart to tests of international parity relationships. The paper proposes and implements a test for conditional heteroskedasticity which in many cases produces strong evidence that the problem is indeed important.

Robert E. Cumby

Financial Studies Division

International Monetary Fund

Washington, D.C. 20431

(202) $477-2887$
Maurice Obstfeld Department of Economics Columbia University New York, NY 10027

(212) 280-5489 
Introduction

International linkages between goods and asset markets are the key factors in exchange rate determination. The scope for activist stabilization policy depends on both the nature of the equilibrium implied by these linkages and the speed with which equilibrium is attained. Two important relationships--purchasing power parity, which links the exchange rate to relative national price levels, and uncovered interest-rate parity, which links the expected future path of the exchange rate to relative nominal interest rates-have received extensive empirical attention in recent years and are main building blocks of several empirical exchange rate models. I/ The purpose of this paper is to review and extend recent empirical evidence on these classical parity relationships within a rationalexpectations framework.

When an economy is small and both classical parity relations hold even in the short run, monetary policy cannot influence the ex ante real rate of interest. Insofar as the ex ante real rate is an important determinant of saving and investment decisions, an important channel for stabilization policy disappears. $2 /$ In theoretical models of Dornbusch (1976) and Mussa (1982), temporary price-level stickiness allows money to influence the real interest rate in the short run even though uncovered parity holds exactly. Portfolio-balance models of exchange-rate determination (such as those of Branson (1979) and Girton and Henderson (1977)), stress imperfect substitution between bonds of different currency denomination. In these models, central banks can influence real interest rates if they can alter relative outside debt supplies.

As emphasized by Roll and Solnik (1979), among others, the classical 
parity relations need not hold in a setting of uncertainty and risk aversion, even when prices are fully flexible and agents efficiently exnloit all welfareaugmenting arbitrage opportunities. 3 - Unless at least one parity relationship fails, monetary policy cannot affect the expected real rate of interest; but the invalidity of a parity condition does not, in itself, imply that monetary policy has this power (see Henderson (this volume) and Obstfeld (1982b)). Thus, the series of tests performed below is at best a single component of a more extensive inquiry into the role of monetary policy in the open economy.

A central theme in our review of empirical work is the conditional heteroskedasticity of inflation and exchange rate forecast errors, and the bias this econometric problem may impart to tests of international parity relationships. Below, we propose and implement a test for conditional heteroskedasticity which in many cases produces strong evidence that the problem is indeed important.

The paper is organized as follows. Section I reviews the classical parity conditions and examines the recent behavior of bilateral ex post real interest rate differentials between the United States and the lnited Kingdom, Germany, Switzerland, Canada, and Japan. Section II carries out bilateral tests of ex ante real interest rate equality between the U.S. and these countries. Section III is devoted to empirical tests of uncovered interestrate parity. Finally, Section IV tests the inpothesis that relative purchasing power parity has held ex ante during the recent era of exchange rate flexibility.

I. Classical Parity Relationships and Real Interest Rates

To facilitate formal discussion of the classical narity relations, we 
introduce the following notation:

$P_{t}=$ price level in the "home" country at the end of period $t$;

$P_{t}^{*}=$ price level in the "foreign" country at the end of period $t$;

$S_{t}=$ the exchange rate at the end of period $t$, defined as the homecurrency price of foreign currency;

$R_{k, t}=\ln \left(1+I_{k, t}\right)$, where $I_{k, t}$ is the home-country k-period nominal interest rate at the end of period $t$;

$R_{k, t}^{\star}=\ln \left(1+I_{k, t}^{*}\right)$, where $I_{k, t}^{*}$ is the foreign-country k-period nominal interest rate at the end of period $t$;

$E_{t}(\cdot)=$ Conditional expectation operator, based on information available at the end of period $t$.

Purchasing power parity (PPP), in its relative form, states that the rate at which the relative price of two currencies changes over time must equal the difference between the national inflation rates. The doctrine of PPP has a long intellectual history, which is surveyed by Frenkel (1976, 1978). Using the foregoing notation, the PPP relation may be witten as

$$
\ln \left(S_{t} / S_{t-1}\right)=\ln \left(P_{t} / P_{t-1}\right)-\ln \left(P_{t}^{*} / P_{t-1}^{*}\right)
$$

An implication of (1) is that relative PPP must be expected to hold ex ante, that is, for any $k$,

$$
E_{t}\left[\ln \left(S_{t+k} / S_{t}\right)\right]=E_{t}\left[\ln \left(P_{t+k} / P_{t}\right)-\ln \left(P_{t+k}^{*} / P_{t}^{*}\right)\right]
$$


and Roll (1979) have suggested an "efficient markets" interpretation of ex ante PPP for a world with low transport costs.

Uncovered interest-rate parity (UIP) states that the nominal interest differential hetween similar bonds denominated in different currencies must equal the expected change in the logarithm of the exchange rate over the holding period. This explanation of international differences in nominal interest rates is associated with fisher (1930). UIP implies that for any $k$,

$$
R_{k, t}-R_{k, t}^{*}=E_{t}\left[\ln \left(S_{t+k} / S_{t}\right)\right]
$$

Condition (3) must hold when bonds differing only in their currencies of denomination are perfect substitutes in investors' portfolios.

Define the expected or ex ante $k$-period real interest rates for the home and foreign countries by

$$
\begin{aligned}
& r_{k, t} \equiv R_{k, t}-E_{t}\left[\ln \left(P_{t+k} / P_{t}\right)\right], \\
& r_{k, t}^{*} \equiv R_{k, t}^{*}-E_{t}\left[\ln \left(P_{t+k}^{*} / P_{t}^{*}\right)\right] .
\end{aligned}
$$

By combining (2) and (3) with (4a) and (4b), we find that

$$
r_{k, t}=r_{k, t}^{*}
$$

Thus, under ex ante relative PPP and uncovered interest-rate parity, ex ante real rates of interest must be equalized internationally. The classical parity relationships imply that policymakers in a small open 


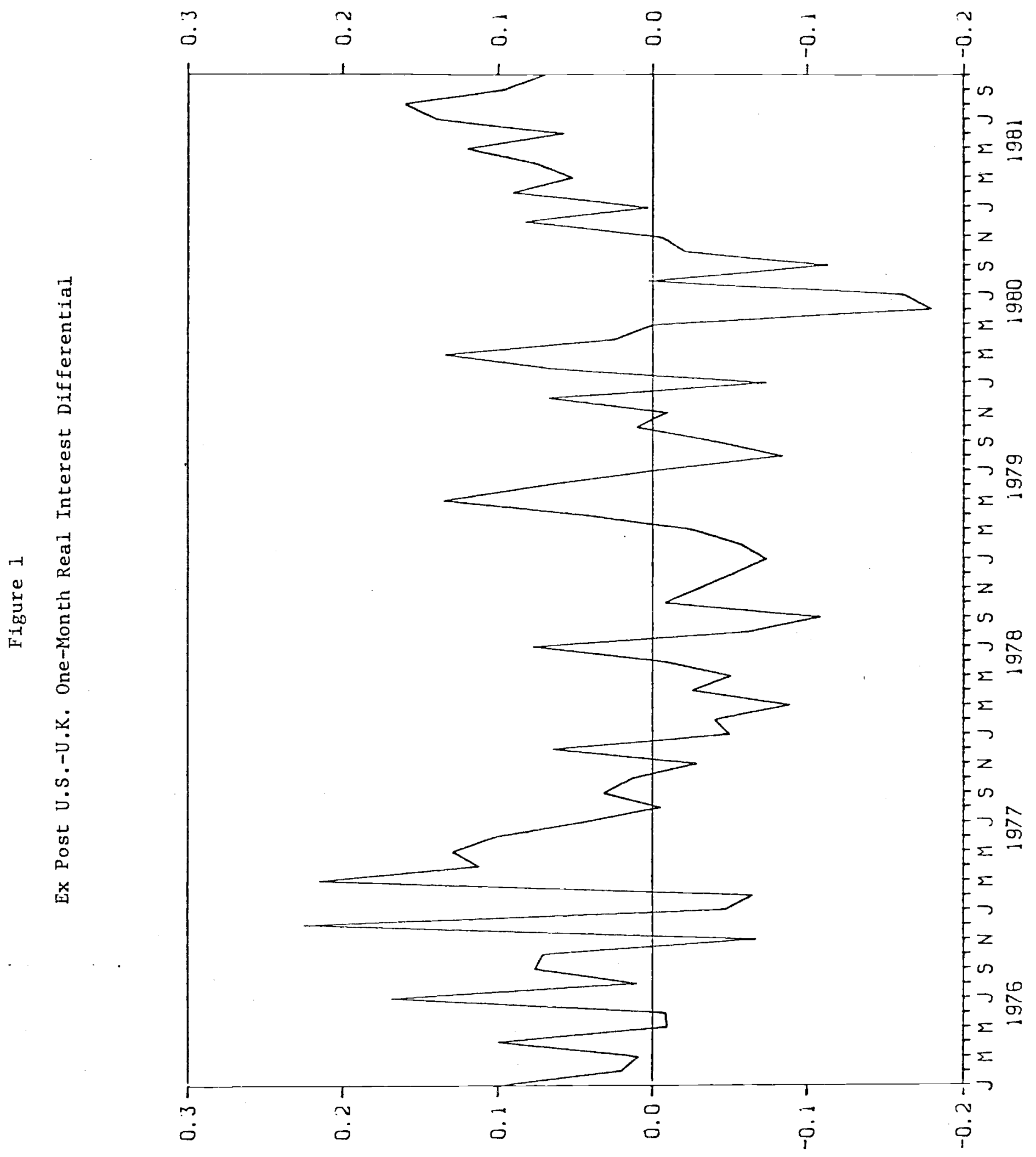


Cumby-obst feld

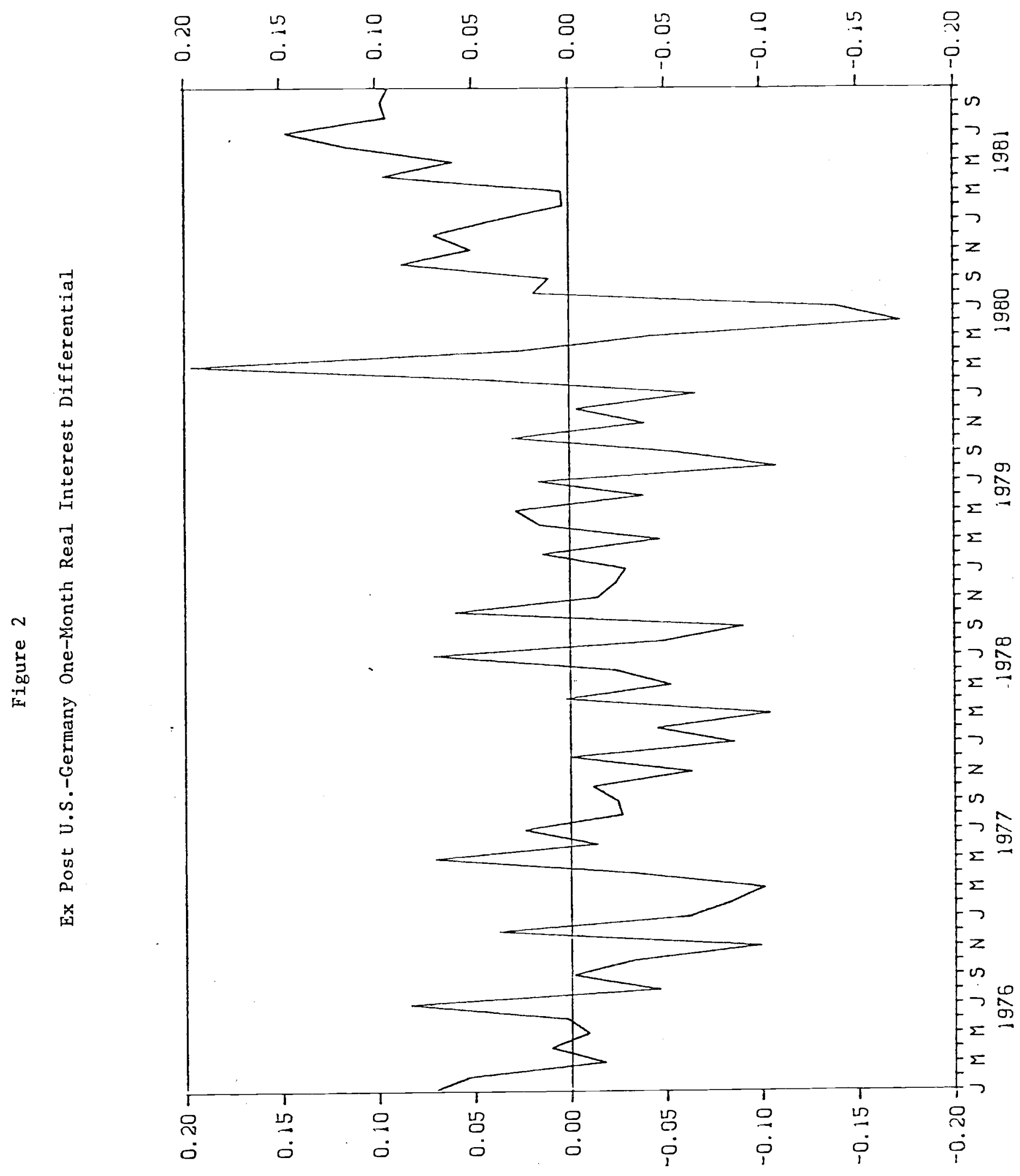


Cumby-nhstfeld

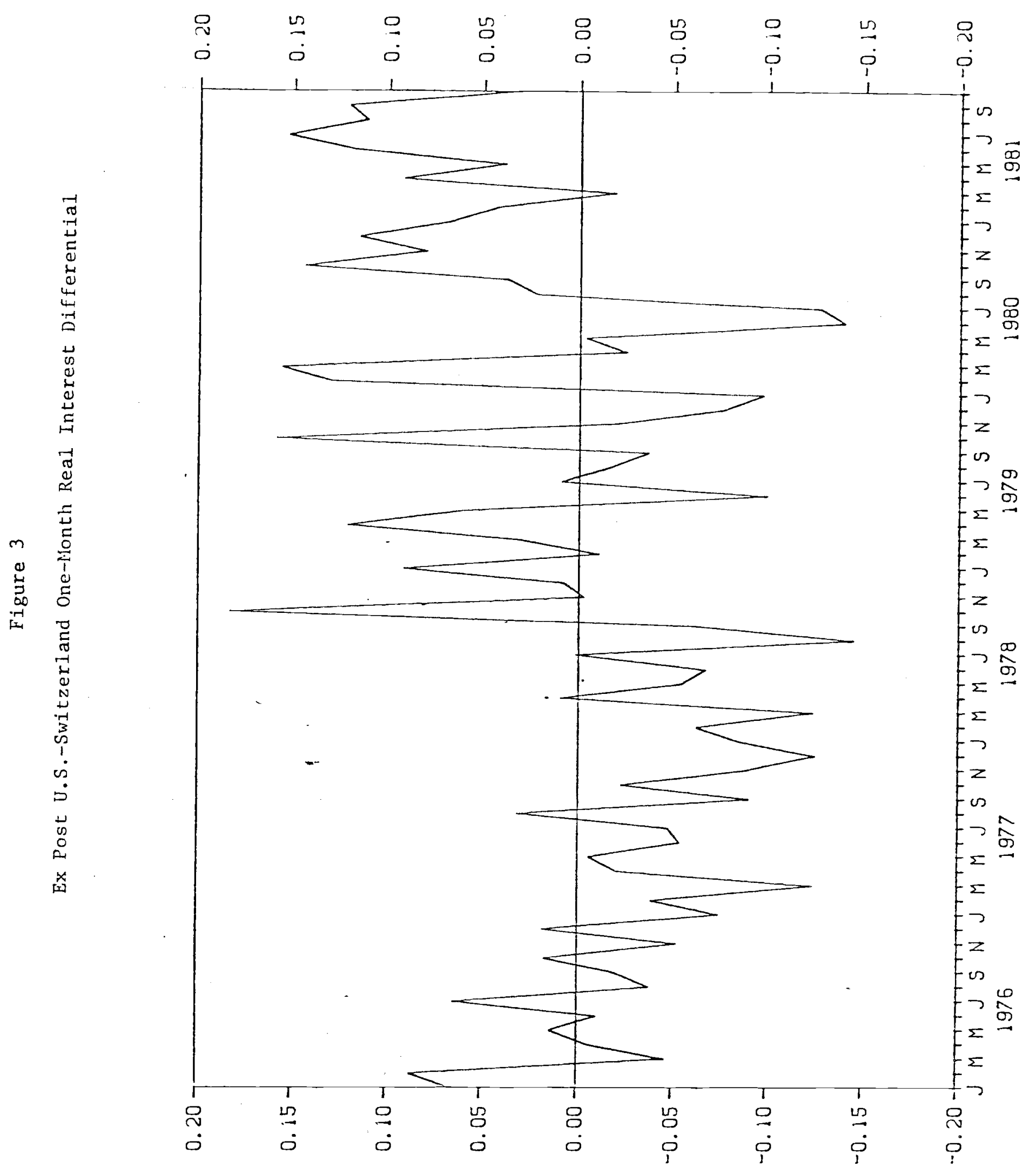


Cumby-Obstfeld

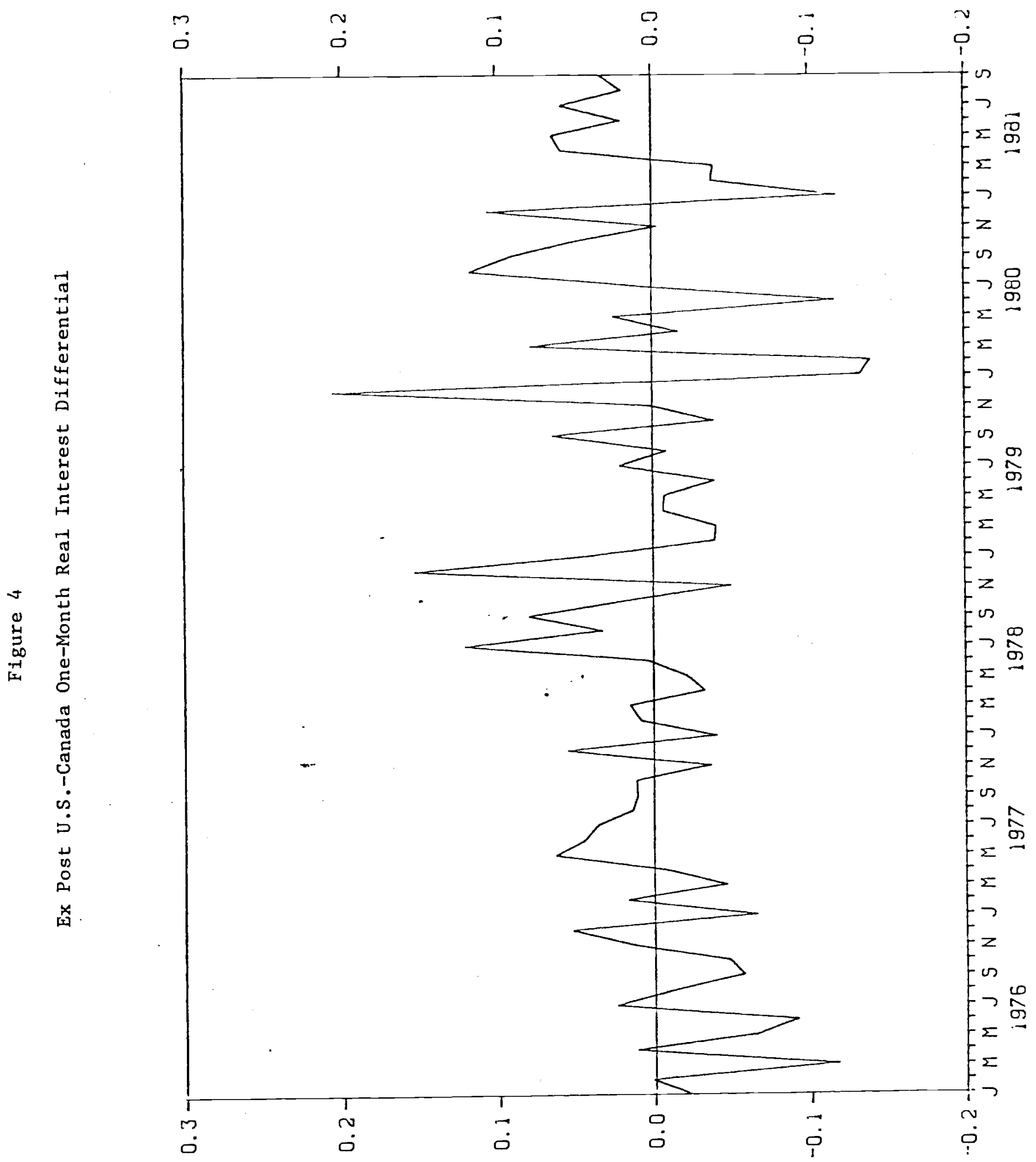


Cumby-Obstfeld

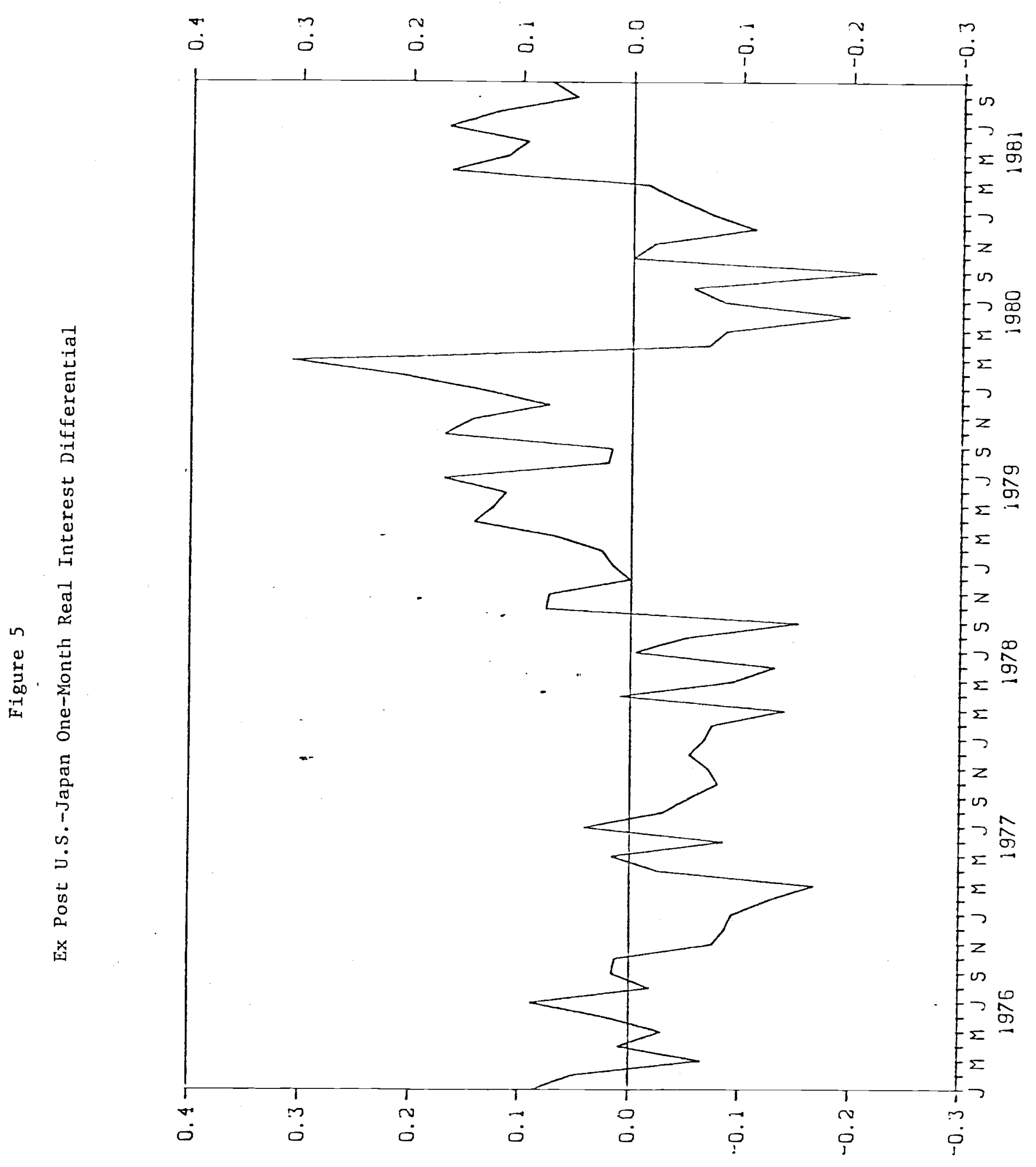


economy cannot affect domestic economic activity through financial policy measures aimed at influencing the expected real interest rate.

Figures 1 through 5 plot monthly series of ex post one-month real interest rate differentials between the United States and the United Kingdom, Germany, Switzerland, Canada, and Japan. The series begin in January 1976 and are based on wholesale price index inflation rates and one-month Eurocurrency deposit rates.

Because the figures use nonoverlapping monthly data involving one-monthahead forecasts, the deviations from ex post real rate equality should be serially uncorrelated and trendless if agents' expectations are rational and real rates are equal across countries ex ante. All five figures suggest some degree of both serial dependence and trend, however. Ex post real rates in both the U.K. and Germany, for example, appear to have been on the whole above those in the U.S. over the period lasting from roughly July 1977 to December 1979.' Between early 1976 and mid-1978, Swiss and Japanese ex post real rates were persistently above those in the U.S. The figures show a pronounced rise in U.S. ex post real rates relative to those in the five other countries beginning around the end of 1980 .

While the figures are suggestive of the existence of ex ante real interest rate differentials over the period since January 1976, conclusive evidence can be provided only by econometric tests. We now turn to these. 
II. The Equality of Ex Ante Real Interest Rates

The equality of ex ante real interest rates across countries has been tested in papers by Hodrick (1979) and Mishkin (1982). Hodrick (1979), using monthly data on three-month rates, performs bilateral tests to compare ex ante real rates in the United States and four other OECD countries over the period of generalized floating. He concludes that the empirical record, though mixed, is not inconsistent with the validity of condition (5). Mishkin (1982) carries out multilateral tests of equality using quarterly data for the U.S. and six other OECD countries. Over both the 1967:II to 1979;II and 1973:II to 1979: I I sample periods, he obtains strong rejections of the hypothesis that ex ante real interest rates in the seven countries were equal.

In this section we test equation (5) taking into account the possible dependence of the conditional covariances of relative inflation forecast errors on nominal interest differentials. Such dependence induces a heteroskedasticity problem which invalidates hypothesis tests unless standard errors are estimated in an appropriate manner. Below, we establish the presence of a conditional heteroskedasticity problem and then use appropriate estimators to conduct a test similar to one of Hodrick's (1979). The results, based on monthly data, are on the whole unfavorable to the hypothesis that expected real interest rates have been equalized internationally in recent years.

\section{A Test of the Hypothesis}

The assumption of rational expectations yields a simple bilateral test of the hypothesis that ex ante real rates are equal across countries. Let $\pi_{t+k}$ and $\pi_{t+k}^{*}$ denote the realized inflation rates in the home and foreign 
countries between the end of period $t$ and the end of period $t+k$. Then

$$
\begin{aligned}
& \pi_{t+k}=E_{t}\left[\ln \left(P_{t+k} / P_{t}\right)\right]+u_{t+k}, \\
& \pi_{t+k}^{*}=E_{t}\left[\ln \left(P_{t+k}^{\star} / P_{t}^{\star}\right)\right]+u_{t+k}^{*},
\end{aligned}
$$

where $u_{t+k}$ and $u_{t+k}^{*}$ are mean-zero inflation forecast errors uncorrelated with any variables observed by the market by the end of period $t$. Because subsequent forecast errors are not part of that information set, $E\left(u_{t+k} u_{t+k-j}\right)$, $E\left(u_{t+k}^{*} u_{t+k-j}^{*}\right) \neq 0$ for $j<k$ even though $E\left(u_{t+k} u_{t+k-j}\right)=E\left(u_{t+k}^{*} u_{t+k-j}^{\star}\right)=0$ for $j \geq k$. Combining (4a), (4b), and (5) with (6a) and (6b), we obtain the relation

$$
\pi_{t+k}-\pi_{t+k}^{*}=R_{k, t}-R_{k, t}^{\star}+u_{t+k}-u_{t+k}^{*}
$$

Because the composite forecast error $e_{t+k} \equiv u_{t+k}-u_{t+k}^{*}$ is uncorrelated with $R_{k, t}$ and $R_{k, t}^{*}$ (both of which are known to agents at the end of period $t$ ), the parameters $a$ and $b$ in the regression equation

$$
\pi_{t+k}-\pi_{t+k}^{*}=a+b\left(R_{k, t}-R_{k, t}^{*}\right)+e_{t+k}
$$

may be estimated consistently by ordinary least squares (OLS). A test of the hypothesis $\left[\begin{array}{ll}a & b\end{array}\right]^{-}=\left[\begin{array}{ll}0 & 1\end{array}\right]^{-}$is a test of the hypothesis that expected real interest rates are equal in the home and foreign country. 4 / While OLS is consistent when applied to equation (8), it is generally 
inefficient relative to an instrumental-variables estimator of the type discussed by Cumby, Huizinga, and Obstfeld (1982) and by Hansen (1982). / Because $e_{t+k}$ is orthogonal to any variables in agents' information set at time $t$, many instrumental variables are available. Below, we use third-country interest rates as additional instruments to estimate the parameters of (8) by the two-step two-stage least squares (2S2SLS) technique described by Cumby, Huizinga, and Obstfeld (1982).

Let $Q_{t}$ denote the row vector $\left[1\left(R_{k, t}-R_{k, t}^{\star}\right)\right]$ and stack the $T$ observations on (8) to obtain the regression model $\pi-\pi^{*}=Q d+e$, where $d \equiv[a b]^{-}$. Let $x_{t}$ be a row vector of instrumental variables (including $Q_{t}$ ), all of which are uncorrelated with $e_{t+k}$. Then the 2S2SLS estimate of $d$ can be written as

$$
\hat{\mathbf{d}}=\left(Q^{-} \times \hat{\Omega}^{-1} X^{-} Q^{-1} Q^{-} \times \hat{\Omega}^{-1} X^{-}\left(\pi-\pi^{*}\right),\right.
$$

where $\hat{\Omega}$ is a consistent estimate of $\Omega=\lim _{T \rightarrow \infty}(1 / T) E\left(\lambda^{-} e^{-}-x\right)$. Under standard regularity conditions (which include covariance stationarity of all series), $\sqrt{\mathrm{T}}(\hat{\mathrm{d}}$ - d) converges to a normal random vector with mean zero and asymptotic covariance matrix

$$
P \lim \left(Q^{-} \times \Omega^{-1} X^{-} Q^{-1}\right.
$$

When $X=Q, \hat{d}$ reduces to the OLS estimator $\left(Q^{-} Q^{-1} Q^{-}\left(\pi-\pi^{*}\right)\right.$.

Computation of $\hat{d}$ and its asymptotic covariance matrix requires a consistent estimate of $\Omega$. If we assume that for all $j$, the conditional covariance

$$
E\left(e_{t+k} e_{t+k-j} \mid x_{t}, \ldots, x_{t-j}\right)=\sigma_{j},
$$

a constant, then $\hat{d}$ may be written as 


$$
\hat{d}=\left[Q^{-} X\left(X^{-} \hat{\Sigma} X\right)^{-1} X^{-} Q^{-1} Q^{-} X\left(X^{-} \hat{\Sigma} X\right)^{-1} X^{-}\left(\pi-\pi^{*}\right)\right.
$$

where $\hat{\Sigma}$ is an estimate of the variance-covariance matrix $E\left(e e^{\prime}\right)$, formed using the residuals from a first-step, consistent estimation of (8) (by OLS, say). The matrix

$$
T\left[Q^{-} X\left(X^{-} \hat{\Sigma} X\right)^{-1} X^{\prime} Q^{-1}\right.
$$

provides a consistent estimate of the asymptotic covariance matrix of $\sqrt{\mathrm{T}}(\hat{\mathrm{d}}-\mathrm{d})$ in this special case. (The usual textbook formula for the asymptotic covariance matrix of the two-stage least squares estimator (see Dhrymes (1974)) is based on assumption (10) and the assumption that $\sigma_{j}=0$ for $j>0$. )

Formula (12) is used by Hodrick (1979) to calculate the asymptotic confidence ellipse for OLS estimates of (8). But (12) is not justified, even in the OLS case, unless the conditional covariances of forecast errors with respect to lagged interest differentials are constants. $7 /$ Condition (10) would be valid if the variables included in $x_{t}$ were all strictly exogenous; but that is certainly not the case here. 8/ The validity of (10) is thus an issue of considerable importance in constructing hypothesis tests concerning the coefficients of (8). Below, we describe and implement a test of (10).

When (10) fails, estimation of the matrix $\Omega$ is more involved. Hansen (1982) suggests the following procedure. As before, generate estimates $\hat{e}_{t}$ of the residuals of (8) using some consistent (but not necessarily efficient) estimation procedure, for example, OLS. Then, calculate a consistent estimate $\hat{s}(\xi)$ of the spectral density matrix of the vector stochastic process $\left\{x_{t}^{-} \hat{e}_{t}\right\}$,

$$
s(\xi)=\frac{1}{2 \pi} \sum_{\ell=-\infty}^{\infty} \exp (-i \xi \ell)\left(x_{t}^{-} \dot{e}_{t} \hat{e}_{t-l}^{-} x_{t-l}\right) .
$$


A consistent estimate of $\Omega$ is provided by $2 \pi \hat{s}(0)$. This heteroskedasticityconsistent covariance matrix estimator is convenient, as it does not require detailed specification of either the nature of the heteroskedasticity or the nature of the serial correlation in the residuals of (8).

A Test of Conditional Homoskedasticity

To determine the appropriate estimator for the matrix $\Omega$ in (9), the empirical validity of assumption (10) must be examined. Here, we test (10) for the case $j=1$. In that case, (10) asserts that

$$
E\left(e_{t+k}^{2} \mid x_{t}\right)=\sigma^{2}
$$

a constant, so that the forecast error $e_{t+k}$ is conditionally homoskedastic with respect to time-t values of the instrumental variables. Rejection of (14) is clearly a sufficient indication that formula (12) is inappropriate and may lead to faulty inferences.

Since our ultimate goal is to test whether $a=0$ and $b=1$ in (8), it is reasonable to test for conditional heteroskedasticity under the tentative assumption that the null hypothesis of ex ante real interest rate equality is valid. That assumption implies that $e_{t+k}$ is simply the composite forecast error $\pi_{t}-\pi_{t}^{*}-R_{k, t}+R_{k, t}^{*}$, which is obervable. By the properties of conditional means, the random variable

$$
n_{t+k} \equiv e_{t+k}^{2}-E\left(e_{t+k}^{2} \mid x_{t}\right)
$$

has unconditional mean zero and is uncorrelated with any variable in the information set generated by $x_{t}$. If (14) is valid, $\eta_{t+k}=e_{t+k}^{2}-\sigma^{2}$, 
and so (14) can be tested by estimating an equation of the form

$$
e_{t+k}^{2}=\alpha+B\left(R_{k, t}-R_{k, t}^{*}\right)+\gamma\left(R_{k, t}-R_{k, t}^{*}\right)^{2}+\eta_{t+k} \cdot
$$

A test of the hypothesis $B=\gamma=0$ is a test of conditional homoskedasticity. Because $n_{t+k}$ is uncorrelated with the regressors in (15) (all of which are included in the information set generated by instrumental variables dated $t$ or earlier), OLS yields consistent parameter estimates. But 2S2SLS again yields an efficiency gain in general. Any variables in the information set generated by $x_{t}$ may be used as instrumental variables. $10 /$

The foregoing test is similar in spirit to one proposed by white (1980) for cross-sectional estimation environments. White suggests regressing estimated equation residuals on cross-products of regressors. His procedure thus imposes no a priori coefficient constraints. The present setting, however, is one in which a simple null hypothesis is to be tested. Absence of conditional heteroskedasticity when the null is imposed is clearly necessary if formula (12) is to lead to valid inferences.

Table I contains the homoskedasticity test results based on monthly data. Five countries--the United Kingdom, Germany, Switzerland, Canada, and Japan--are compared with the United States in the tests of ex ante real interest rate equality carried out below. Choosing an appropriate price index and interest rate is in itself an issue of considerable importance. Thus, the tests are performed for both consumer price index (CPI) and wholesale price index (WPI) inflation rates and for three nominal interest rates, the one-month and threemonth Eurocurrency rates and a domestic three-month money-market rate. $11 /$ All the resulting possibilities are represented in Table I. 12/

The results illustrate the empirical relevance of the conditional hetero- 
Table 1

Conditional Homoskedasticity of Inflation Forecast Errors

\begin{tabular}{|c|c|c|c|}
\hline Countries & Interest Rate & Price Index & Test Statistic \\
\hline U.S./U.K. & I-month Euro & CPI & 3.42 \\
\hline U.S./U.K. & I-month Euro & WPI & 2,58 \\
\hline U.S./U.K. & 3-month Euro & CPI & $7.21 *$ \\
\hline U.S./U.K. & 3-month Euro & WPI & $7.53 *$ \\
\hline U.S./U.K. & 3-month money market & $\mathrm{CPI}$ & $8.24 *$ \\
\hline U.S./U.K. & 3-month money market & WPI & $9.40 * *$ \\
\hline U.S./Germany & 1-month Euro & $\mathrm{CPI}$ & $6.20 *$ \\
\hline U.S./Germany & 1-month Euro & WPI & 4.23 \\
\hline U.S./Germany & 3-month Euro & $\mathrm{CPI}$ & $16.54 \div \star$ \\
\hline U.S./Germany & 3-month Euro & WPI & $11.00 * *$ \\
\hline U.S./Germany & 3-month money market & CPI & $32.35 \div$ \\
\hline U.S./Germany & 3-month money market & WPI & $72.07 \div *$ \\
\hline U.S./Switzerland & 1-month Euro & $\mathrm{CPI}$ & 4.45 \\
\hline U.S./Switzerland & I-month Euro & WPI & $11.97 \div *$ \\
\hline U.S./Switzerland & 3-month Euro & $\mathrm{CPI}$ & $74.08 * *$ \\
\hline U.S./Switzerland & 3-month Euro & WPI & $42.38 \div \div$ \\
\hline U.S./Switzerland & 3-month money market & $\mathrm{CPI}$ & $58.22 * *$ \\
\hline U.S./Switzerland & 3-month money market & WPI & $11.64 * *$ \\
\hline U.S./Canada & 1-month Euro & CPI & 2.56 \\
\hline U.S./Canada & I-month Euro & WPI & 4.22 \\
\hline U.S./Canada & 3-month Euro & $\mathrm{CPI}$ & $21.49 \div *$ \\
\hline U.S./Canada & 3-month Euro & WPI & $9.93 \div *$ \\
\hline
\end{tabular}


Table 1

(CONTINUED)

\begin{tabular}{|c|c|c|c|}
\hline Countries & Interest Rate & Price Index & Test Statistic \\
\hline U.S./Canada & 3-month money market & $\mathrm{CPI}$ & 2.19 \\
\hline U.S./Canada & 3-month money market & WPI & 5.95 \\
\hline U.S./Japan & 1-month Euro & CPI & 2.14 \\
\hline U.S./Japan & 1-month Euro & WPI & 2.55 \\
\hline U.S./Japan & 3-month Euro & CPI & $127.83 \div *$ \\
\hline U.S./ Japan & 3-month Euro & WPI & $6.23 *$ \\
\hline U.S./Japan & 3-month money market & $\mathrm{CPI}$ & $9.58 * *$ \\
\hline U.S./ Japan & 3-month money market & WPI & $35.85 * \star$ \\
\hline
\end{tabular}

Note: Data for tests using one-month interest rates run from January 1976 to September 1981. Data for tests using three-month interest rates run from January 1976 to July 1981. The test statistic is distributed asymptotically as $x^{2}(2)$. * = rejection at the 5 percent level; $* *=$ rejection at the 1 percent level. 
skedasticity probjem in tests of real interest rate equality. In twenty of the thirty tests, the hypothesis of conditional homoskedasticity can be rejected at the 5 per cent level. In five of the remaining cases, the hypothesis can be rejected at the 20 percent level. Taken together, these results contradict the simplifying assumptions under which formula (12) is a consistent estimator of the asymptotic covariance matrix. Accordingly, a heteroskedasticity-consistent covariance matrix estimator is used to obtain the test results analyzed below.

Empirical Results

Tables $2 a, 2 b$, and $2 c$ report the results of bilateral tests of equality between the U.S. real interest rate and those of the U.K., Germany, Switzerland, Canada, and Japan. $\frac{13 /}{}$ Except in the U.K. and Jananese cases, equality is strongly rejected for all combinations of price index and interest rate. The rejections in tests using onshore money-market interest rates (Table 2c) may in some cases be plausibly ascribed to the existence or prospect of capital controls. However, the rejections are aimost equally strong when Eurocurrency interest rates are used in place of money-market rates; and arbitrage between differently denominated Eurocurrency deposits has not been restricted. $\frac{14 /}{}$ on the whole, it seems difficult to explain the rejections of real interest rate equality by appealing to institutional factors that hinder international movements of capital. In the case of the U.K., the evidence is on the whole very favorable to the hypothesis that ex ante real rates in the U.S. and U.K. have been equal during the recent years of floating exchange rates. While the U.S./U.K. test statistic lies in the 5 percent critical region in one 
Table 2a

Equality of Ex Ante Real Interest Rates: One-Month Eurocurrency Rates (January 1976 - September 1981)

\begin{tabular}{|c|c|c|c|c|}
\hline Countries & Price Index & $\hat{a}$ & $\hat{b}$ & Test Statistic \\
\hline U.S./U.K. & $\mathrm{CPI}$ & $\begin{array}{l}-.0119 \\
(.0086)\end{array}$ & $\begin{array}{l}.7362 \\
(.2351)\end{array}$ & 2.22 \\
\hline U.S./U.K. & WPI & $\begin{array}{l}-.0216 \\
(.0093)\end{array}$ & $\begin{array}{l}.8197 \\
(.2713)\end{array}$ & 5.34 \\
\hline U.S./Germany & $\mathrm{CPI}$ & $\begin{array}{l}.0278 \\
(.0095)\end{array}$ & $\begin{array}{l}.5031 \\
(.2264)\end{array}$ & $9.13 *$ \\
\hline U.S. / Germany & WPI & $\begin{array}{l}.0484 \\
(.0148)\end{array}$ & $\begin{array}{l}-.1371 \\
(.3529)\end{array}$ & $11.21 * *$ \\
\hline U.S./Switzerland & $\mathrm{CPI}$ & $\begin{array}{l}.0350 \\
(.0125)\end{array}$ & $\begin{array}{l}.3708 \\
(.1970)\end{array}$ & $10.25 * *$ \\
\hline U.S./Switzerland & WPI & $\begin{array}{l}.0844 \\
(.0178)\end{array}$ & $\begin{array}{l}-.3187 \\
(.2655)\end{array}$ & $25.16 * *$ \\
\hline U.S. / Canada & $\mathrm{CPI}$ & $\begin{array}{l}.0010 \\
(.0054)\end{array}$ & $\begin{array}{l}.4043 \\
(.1915)\end{array}$ & $12.61 \div \frac{\pi}{x}$ \\
\hline U.S. / Canada & WPI & $\begin{array}{l}-.0111 \\
(.0070)\end{array}$ & $\begin{array}{l}.0317 \\
(.3429)\end{array}$ & $8.01 *$ \\
\hline U.S./Japan & $\mathrm{CPI}$ & $\begin{array}{l}-.0028 \\
(.0177)\end{array}$ & $\begin{array}{l}.9623 \\
(.2902)\end{array}$ & .24 \\
\hline U.S./Japan & WPI & $\begin{array}{l}.0379 \\
(.0125)\end{array}$ & $\begin{array}{l}.0467 \\
(.2350)\end{array}$ & $16.81 * *$ \\
\hline
\end{tabular}

Note: Standard errors appear in parentheses. The test statistic is distributed asymptotically as $x^{2}(2) . *=$ rejection at the 5 percent level; $* *$ rejection at the 1 percent level. 
Table 2b

Equality of Ex Ante Real Interest Rates: Three-Month Eurocurrency Rates (January 1976 - July 1981)

\begin{tabular}{|c|c|c|c|c|}
\hline Countries & Price Index & $\hat{a}$ & $\hat{b}$ & Test Statistic \\
\hline U.S./U.K. & $\mathrm{CPI}$ & $\begin{array}{l}-.0156 \\
(.0084)\end{array}$ & $\begin{array}{l}.7464 \\
(.2135)\end{array}$ & 3.47 \\
\hline U.S./U.K. & WPI & $\begin{array}{l}-.0165 \\
(.0093)\end{array}$ & $\begin{array}{l}1.0665 \\
(.1544)\end{array}$ & 4.15 \\
\hline U.S./Germany & $\mathrm{CPI}$ & $\begin{array}{l}.0380 \\
(.0075)\end{array}$ & $\begin{array}{l}.2997 \\
(.1520)\end{array}$ & $26.02 \dot{x}$ \\
\hline U.S./Germany & WPI & $\begin{array}{l}.0488 \\
(.0122)\end{array}$ & $\begin{array}{c}-.0972 \\
(.2690)\end{array}$ & $17.68 * *$ \\
\hline U.S./Switzerland & CPI & $\begin{array}{l}.0335 \\
(.0085)\end{array}$ & $\begin{array}{l}.2945 \\
(.1436)\end{array}$ & $25.32 \% x$ \\
\hline U.S./Switzerland & WPI & $\begin{array}{l}.0815 \\
(.0137)\end{array}$ & $\begin{array}{l}-.2740 \\
(.1883)\end{array}$ & $46.04 * *$ \\
\hline U.S./Canada & CPI & $\begin{array}{l}.0076 \\
(.0040)\end{array}$ & $\begin{array}{l}.3302 \\
(.1238)\end{array}$ & $62.72 * *$ \\
\hline U.S./Canada & WPI & $\begin{array}{l}-.0091 \\
(.0039)\end{array}$ & $\begin{array}{l}.2541 \\
(.1816)\end{array}$ & $17.35 * *$ \\
\hline U.S./Japan & CPI & $\begin{array}{l}.0060 \\
(.0107)\end{array}$ & $\begin{array}{c}.8323 \\
(.1806)\end{array}$ & 1.40 \\
\hline U.S./Japan & WPI & $\begin{array}{c}.0446 \\
(.0114)\end{array}$ & $\begin{array}{l}-.1133 \\
(.2223)\end{array}$ & $26.06 * *$ \\
\hline
\end{tabular}

Note: Standard errors appear in parentheses. The test statistic is distributed asymptotically as $x^{2}(2) . *=$ rejection at the 5 percent level; $* *=$ rejection at the 1 percent level. 
Table 2c

Equality of Ex Ante Real Interest Rates: Domestic Money Market Rates (January 1976 - July 1981)

\begin{tabular}{|c|c|c|c|c|}
\hline Countries & Price Index & $\hat{a}$ & $\hat{\mathrm{b}}$ & Test Statistic \\
\hline U.S./U.K. & $\mathrm{CPI}$ & $\begin{array}{l}-.0134 \\
(.0074)\end{array}$ & $\begin{array}{l}.7554 \\
(.2400)\end{array}$ & 3.34 \\
\hline U.S./U.K. & WPI & $\begin{array}{l}-.0153 \\
(.0102)\end{array}$ & $\begin{array}{l}1.1464 \\
(.1974)\end{array}$ & $6.34 \%$ \\
\hline U.S./Germamy & CPI & $(.0379)$ & $\begin{array}{c}.3137 \\
(.1276)\end{array}$ & $78.85 * *$ \\
\hline U.S./Germany & WPI & $\begin{array}{l}.0355 \\
(.0088)\end{array}$ & $\begin{array}{l}.1643 \\
(.2569)\end{array}$ & $16.44 \div$ \\
\hline U.S./Switzerland & CPI & $\begin{array}{l}.0352 \\
(.0074)\end{array}$ & $\begin{array}{l}.3451 \\
(.1438)\end{array}$ & $23.11 * \div$ \\
\hline U.S./Switzerland & WP I & $\begin{array}{l}.0707 \\
(.0108)\end{array}$ & $\begin{array}{l}-.1144 \\
(.1461)\end{array}$ & $58.37 \div \div$ \\
\hline U.S./Canada & $\mathrm{CPI}$ & $\begin{array}{l}.0018 \\
(.0049)\end{array}$ & $\begin{array}{l}.2721 \\
(.1015)\end{array}$ & $73.85 \div \star$ \\
\hline U.S./Canada & WPI & $\begin{array}{l}-.0056 \\
(.0046)\end{array}$ & $\begin{array}{l}.2942 \\
(.2032)\end{array}$ & $14.60 \div *$ \\
\hline U.S. / Japan & CPI & $(.0180)$ & $\begin{array}{l}.7229 \\
(.1822)\end{array}$ & 5.47 \\
\hline U.S./Japan & WPI & $\begin{array}{l}.0385 \\
(.0097)\end{array}$ & $\begin{array}{l}-.5492 \\
(.2290)\end{array}$ & $48.06 * *$ \\
\hline
\end{tabular}

Note: Standard errors appear in parentheses. The test statistic is distributed asymptotically as $\chi^{2}(2) . \star \star *=$ rejection at the 5 percent level; $\star *=$ rejection at the 1 percent level. 
case and is quite high in the others, the large size of the estimated constant term (a) relative to its estimated standard error is often the cause. In contrast, the estimated slope coefficient (b) is, in half the cases, within a standard deviation of unity. This evidence is consistent with the existence of a constant ex ante real interest differential between the U.S. and the U.K. The evidence therefore suggests that real interest rates in the two countries, though possibly different, are closely linked.

Tests for Japan using CPI inflation rates and Eurocurrency interest rates support the hypothesis of real interest rate equality. When WPI inflation rates are used in defining real interest rates, however, the hypothesis is easily rejected. Use of the CPI inflation rate together with the domestic money-market nominal interest rate yields a chi-square statistic that is quite close to the critical value of 5.99 .

An interesting feature of the results is that nominal interest differentials have significant explanatory power in equations with the CPI inflation differential as the dependent variable, but do not usually help in forecasting relative WPI inflation rates. The U.K. is again an exception in this respect: Nominal U.S.-U.K. interest differentials are significant (and relatively unbiased) predictors of CPI and WPI inflation rates. The greater importance of the interest differential in CPI regressions is not surprising, for the expected future CPI is probably a better measure of the anticipated future "real" value of money to consumers than is the expected WPI. $15 /$ The tests demonstrate that ex ante real interest rate equality is often rejected decisively over the recent floating exchange rate period. In an attempt to shed light on the reasons for rejection, we now examine the two components of the hypothesis, uncovered interest parity and ex ante purchasing power parity. 
III. Expectations and Nominal Interest Differentials

The hypothesis that expected exchange-rate movements offset nominal interest differentials so as to equalize expected nominal yields internationally has been tested extensively. Work in this area by Frenkel (1981) generally supports the view that uncovered interest-rate parity (UIP) has held quite closely over the period of generalized floating. However, a number of other studies reject the same hypothesis quite strongly (see Bilson (1981), Cumby and Obstfeld (1981), Geweke and Feige (1979), Hakkio (1981), Hansen and Hodrick (1980, 1983), Hsieh (1982), and Longworth (1981), among others).

We discuss below some econometric issues that arise in tests of UIP. Among these, once again, is the problem of conditional heteroskedasticity, which is found to be important in the recent data. Tests of UIP which take this problem into account are performed, and these provide strong evidence against that hypothesis.

A Test of the Hypothesis

In the absence of default risk or transaction costs, covered interest arbitrage equates the forward premium on foreign exchange to the nominal interest differential between home- and foreign-currency bonds. Keynes (1923) provides the classic exposition. Denoting by $F_{k, t}$ the $k$-period forward price of foreign exchange, the covered interest parity condition may be written as

$$
R_{k, t}-R_{k, t}^{*}=\ln \left(F_{k, t}\right)-\ln \left(S_{t}\right)
$$


Empirical studies such as Frenkel and Levich (1975,1977,1981), McCormick (1979), and Marston (1976) show that (16) holds quite closely in the Eurocurrency market, where the interst-bearing assets being compared have identical default and political risk characteristics.

If UIP holds, then (3) and (16) imply that

$$
E_{t}\left[\ln \left(S_{t+k}\right)\right]=\ln \left(F_{k, t}\right)
$$

or, equivalently, that

$$
\ln \left(S_{t+k}\right)=\ln \left(F_{k, t}\right)+v_{t+k} \text {, }
$$

where $v_{t+k}$, the $k$-period forecast error $\ln \left(S_{t+k}\right)-E_{t}\left[\ln \left(S_{t+k}\right)\right]$, has mean zero and is uncorrelated with information available at the end of period $t$. According to (18), the logarithm of the forward rate is an unbiased predictor of the future spot rate, and one-period ahead forecast errors $(k=1)$ are serially uncorrelated. When UIP fails, (17) becomes

$$
E_{t}\left[\ln \left(S_{t+k}\right)\right]=\ln \left(F_{k, t}\right)+\phi_{t}
$$

where $\phi_{t}$ is a risk premium which may fluctuate through time and may be serially correlated. Recent theoretical work shows that when asset holders are risk averse, market efficiency is consistent with the existence of a nonzero, possibly time-varying, risk premium (see, e,g., Frankel (1979b), Grauer, Litzenberger, and Stehle (1976), Hodrick (1981), Kouri (1977), Stockman (1978), and Stulz $(1981))$. When a nonzero risk premium exists, bonds denominated in different 
currencies are imperfect substitutes in portfolios. The empirical implications of imperfect asset substitutability are that $\ln \left(F_{k, t}\right)$ is not in general an unbiased predictor of $\ln \left(\mathrm{S}_{t+k}\right)$ and that the forward forecast error $\ln \left(S_{t+k}\right)$ - $\ln \left(F_{k, t}\right)$ need not be uncorrelated with information available to the market at time $t$.

Frenkel (1981) tests UIP by estimating the parameters of the equation

$$
\ln \left(S_{t+1}\right)=a+b \ln \left(F_{1, t}\right)+v_{t+1}
$$

using monthly data (sampled from June 1973 to July 1979) on the spot and one-month forward dollar prices of the pound sterling, the French franc, and the Deutschemark. $\frac{16 /}{-}$ A test of the hypothesis $\left[\begin{array}{ll}a & b\end{array}\right]^{\prime}=\left[\begin{array}{ll}0 & 1\end{array}\right]^{\prime}$ is a test of the UIP condition. Frenkel finds that the results of estimation are "broadly consistent" with the hypothesis that nominal interest differentials can be explained entirely by expected exchange rate movements.

A problem with the foregoing test, pointed out by Hansen and Hodrick and by Meese and Singleton (1982), (1980)/ is that the stochastic processes generating the logarithms of spot and forward exchange rates may be nonstationary. Even though least squares estimates of $a$ and $b$ in (20) will often be consistent in a nonstationary estimation environment, the usual asymptotic theory invoked to construct hypothesis tests becomes inapplicable. Mussa's (1979) observation that the logarithms of exchange rates seem to follow approximately a random walk is supported by statistical tests implemented by Meese and Singleton (1982) . These tests, which involve the U.S. dollar's exchange rate against the Canadian dollar, the Swiss franc, and the Deutschemark, cannot reject the hypothesis that unit roots are present in the univariate autoregressive representations of the logarithms of spot and forward rates. The Meese-Singleton 
findings suggest that the possibility of nonstationarity needs to be taken seriously in designing and evaluating hypothesis tests involving exchange rates.

A procedure that often avoids the unit-root problem is to test whether $a=0$ and $b=1$ in the equation

$$
\ln \left(S_{t+k} / S_{t}\right)=a+b \ln \left(F_{k, t} / S_{t}\right)+v_{t+k}
$$

Under the hypothesis of UIP, (21) is equivalent to (20), and states that the $k$-period forward premium is the market's expectation of the change in the logarithm of the spot rate over the next $k$ periods. Like the tests cited above as rejecting UIP, the test just described works in terms of first differences rather than levels. Thus, the asymptotic theory used in testing is more likely to be justifiable.

Equation (21) is estimated below, and the hypothesis that $a=0$ and $\mathrm{b}=1$ is tested. The tests are bilateral (unlike Bilson's (1981)), but expand Frenkel's (1981) information set by using third-currency forward premia observed at time $t$ (which are uncorrelated with the disturbance $v_{t+k}$ ) as instrumental variables in forming 2S2SLS estimates of [a b] * This yields parameter estimates more efficient than those produced by OLS, and so a more stringent test of the null hypothesis. Like Hansen and Hodrick (1980), we use weekly data on three-month forecasts.

\section{A Test of Conditional Homoskedasticity}

Tests of UIP have almost universally assumed that the conditional covariances of forecast errors do not depend on lagged forward premia. $13 /$ Because 
the forward premium is not a strictly exogenous variable, this assumption may be false, in which case the customary standard-error estimators have no asymptotic justification. As in the previous section, it is therefore of interest to test the conditional homoskedasticity assumption formally under the null hynothesis that UIP holds.

This can once again be done by estimating the equation

$$
v_{t+k}^{2}=a+\beta \ln \left(F_{k, t} / S_{t}\right)+\gamma \ln \left(F_{k, t} / S_{t}\right)^{2}+\varepsilon_{t+k}
$$

Under conditional homoskedasticity, the expected value of $v_{t+k}^{2}$ conditional on forward premia observed at $t i m e t$ is a constant. Thus, we should find that $B=\gamma=0$ in (22). As before, any variable in the conditioning set may be used as an instrumental variable in forming 2S2SLS estimates of (22). Table 3 reports the results of testing the conditional homoskedasticity of three-month forward rate forecast errors. $18 /$ The tests involve the U.S. dollar's exchange rate against the pound sterling, the Deutschemark, the Swiss franc, the Canadian dollar, and the Japanese yen. Heekly data running from 7 January 1976 to 24 June 1981 are employed. The data are aligned to account for timing problems caused by bank holidays and weekends. 19 /

In four of five cases, the null hypothesis of conditional homoskedasticity is strongly rejected. For the Canadian dollar, there is weak evidence against conditional homoskedasticity. The results suggest that a heteroskedasticity consistent covariance matrix estimator should be used in conducting hypothesis tests on the coefficients of equation (21). 
TABLE 3

Conditional Homoskedasticity of Forward-Rate Forecast Errors (Weekly Data, January 1976 - June 1981)

Exchange Rate

U.S. /U.K.

U.S. / Germany

U.S./Switzerland

U.S. /Canada

U.S./Japan
Test Statistic

$308.13 * *$

$26.38 * *$

13. $20 * *$

2. 57

$141.05 * *$

Note: The test statistic is distributed asymptotically as $x^{2}(2)$. * = rejection at the 5 percent level; ** = rejection at the 1 percent level. 
Empirical Results

Results of estimating (21) and testing UIP appear in Table $4 . \frac{20 / \text { In }}{}$ all cases save that of the dollar-Deutschemark exchange rate, the null hypothesis of UIP can be rejected at the 5 per cent level. In the case of Canada, however, rejection is entirely due to the large size of a relative to its estimated standard error. As the estimated slope coefficient $\vec{b}$ is quite close to unity, the rejection in the Canadian case cannot be considered very strong.

In four of five cases, the three-month forward premium has on average mispredicted the direction of movement of the subsequent1y observed spot rate. In the remaining case (that of Canada), the slope coefficient, while of the correct sign, is insignificantly different from zero. The test results are on the whole inconsistent with UIP, and they also suggest that forward premia contain little information regarding subsequent exchange-rate fluctuations. As emphasized by Dornbusch (1978, 1980), Frenkel (1981), and Mussa (1979), exchange rate changes over the recent period of floating seem to have been largely unanticipated.

An Additional Test

As a check on the validity of the conclusions reached above, an additional test, suggested by Geweke and Feige (1979) and by Hansen and Hodrick (1980), was performed. If UIP holds, then with weekly data and three-month forward rates, the forward forecast error $v_{t+13}$ must be uncorrelated with any information dated $t$ or earlier. In particular, if $v_{t+13}$ is regressed on a constant, on $v_{t}$, and on the time-t forward forecast errors for the other four currencies, one should not be able to reject the hypothesis that all 
TABLE 4

Tests of Uncovered Interest Parity

(Weekly Data, January 1976 - June 1981)

\begin{tabular}{lccc}
\hline Exchange Rate & $\hat{\mathrm{a}}$ & $\hat{\mathrm{b}}$ & Test Statistic \\
\hline U.S./U.K. & .0086 & -.2881 & $16.16 * \frac{1}{}$ \\
U.S./Germany & $.0156)$ & $(.9741)$ & 3.59 \\
& $(.0113)$ & $(1.7815$ & \\
U.S./Switzerland & .0481 & -2.2145 & $9.11 *$ \\
& $(.0214)$ & $(1.1177)$ & $12.44 * *$ \\
U.S./Canada & -.0076 & .8285 & \\
& $(.0023)$ & $(.7922)$ & $41.58 * *$ \\
U.S./Japan & .0311 & -2.8316 & $(.6740)$ \\
\hline
\end{tabular}

Note: Standard errors appear in parentheses. The test statistic is distributed asymptotically as $x^{2}(2) . \pm=$ rejection at the 5 percent level; $*_{*}=$ rejection at the 1 percent level. 
coefficients cqual zero. The results of this test are reported in Table 5. The equations were estimated by OLS, but the standard errors were calculated using a heteroskedasticity-consistent technique.

Rejection at the 5 percent level again occurs in all cases except that of Germany. Thus, the results of the present test are quite similar to those of Table 4. In addition, most of the estimated constant terms (Canada is the exception) are quite insignificant. None of the rejections in Table 5 appears to be caused exclusively by the large size of an estimated constant term, relative to its standard error, Note that while the present tests are unable to reject UIP for dollar and Deutschemark deposits, tests by Hansen and Hodrick (1980) using a different data sample do reject that hypothesis.

While the two tests performed above cast considerable doubt on the hypothesis of perfect asset substitutability, their results should be interpreted with caution. First, political uncertainties may have introduced an element of default risk into forward transactions during the sample period. A second issue is the so-called "peso problem" (Krasker 1980), which is essentially a problem of finite-sample inference. If agents, over some significant time period, expect a major central bank intervention which does not materialize, nonoverlapping forward forecast errors will be correlated in the sample even if the expectation of intervention is rational in the light of past central bank behavior. While agents would be correct on average given an infinite sample containing infinitely many such episodes, the econometrician has only a finite history at her disposal. The dramatic Federal Reserve-Bundesbank interventions in the fourth quarters of 1978 and 1979 are examples of the type of event which, if incorrectly anticipated ex post, may give rise to a spurious correlation in nonoverlapping forecast errors. 


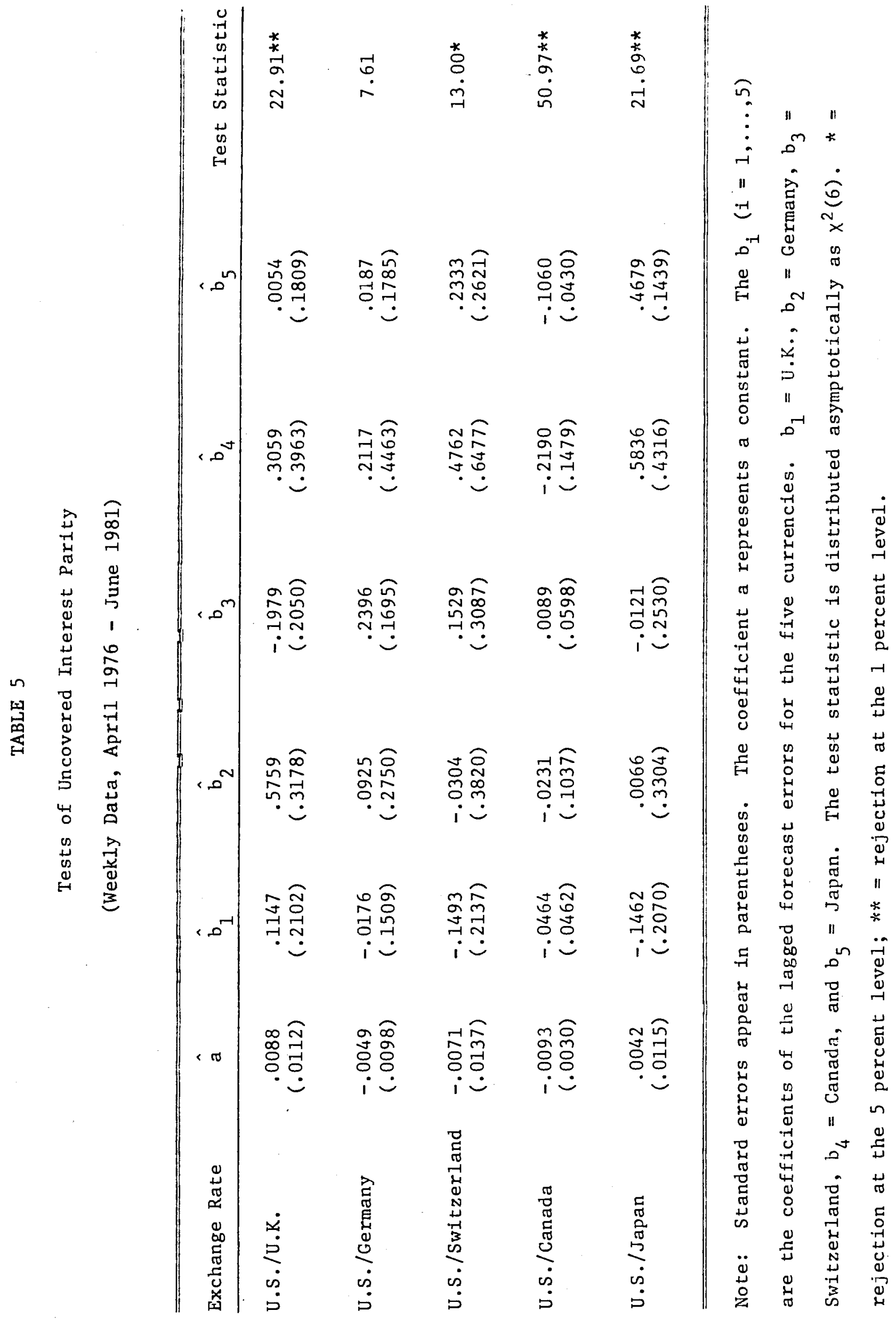


IV. Exchange Rates and National Price Levels

The absolute version of the purchasing power parity (PPP) doctrine has not fared well in econometric tests on recent data, at least not in tests involving the U.S. (see, e.g., Frenke1 (1981) and Krugman (1978)). Figures 6 through 10 display the time series of first differences of the real exchange rates of the U.K., Germany, Switzerland, Canada, and Japan against the U.S. The real exchange rate is defined as the dollar "value" of the foreign WPI d:vided by the U.S. WPI. The figures reveal that for all countries, the floating-rate period has been a period of much higher real exchange-rate variability

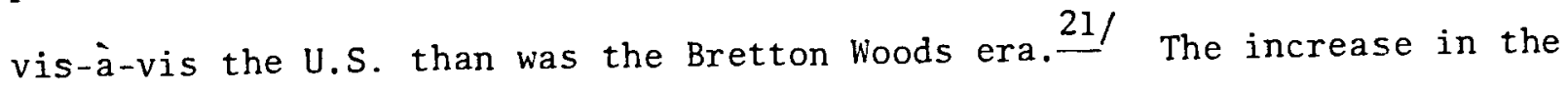
amplitude of deviations from PPP begins abruptly with the adoption of flexible rates. $\underline{\underline{22 /}}$

Here, we test whether relative PPP holds ex ante, that is, whether expected exchange-rate depreciation reflects the expected inflation differential between the home and foreign countries. If ex ante ppp does not hold, ex ante real interest rates will generally differ internationally. As Magee (1978) and Roll (1979) observe, ex ante PPP is under certain assumptions a consequence of the efficiency of international commodity markets. Both Roll (1979) and Frenkel (1981) present evidence that changes in real exchange rates are serially uncorrelated, and thus possess a key property of forecast-error series.

\section{A Test of the Hypothesis}

To design a test of ex ante relative PPP we return to equation (2). By combining (2) with (6a) and (6b) we obtain the equation 
Cumby-Obstfeld

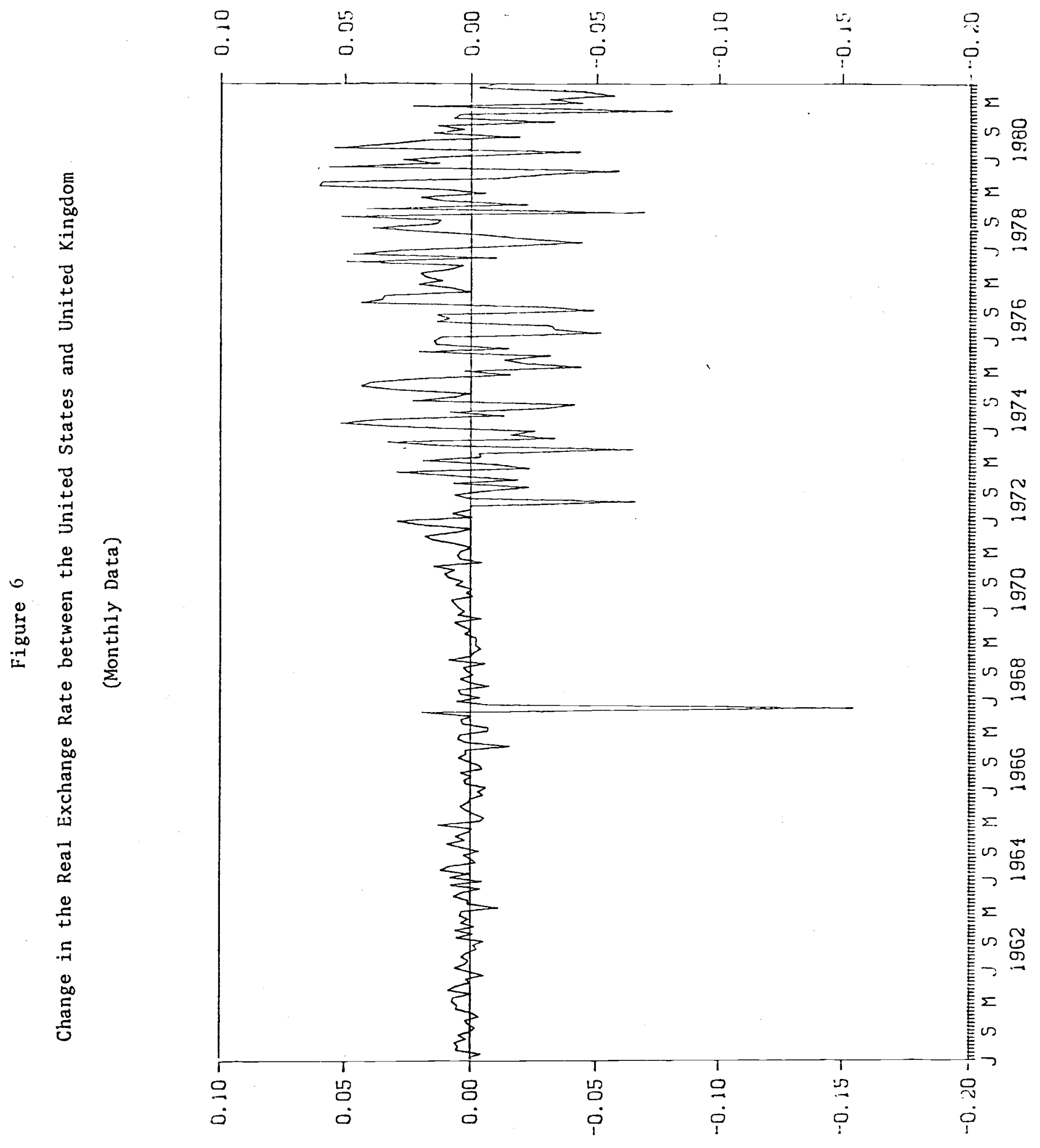


Cumby-bostfeld

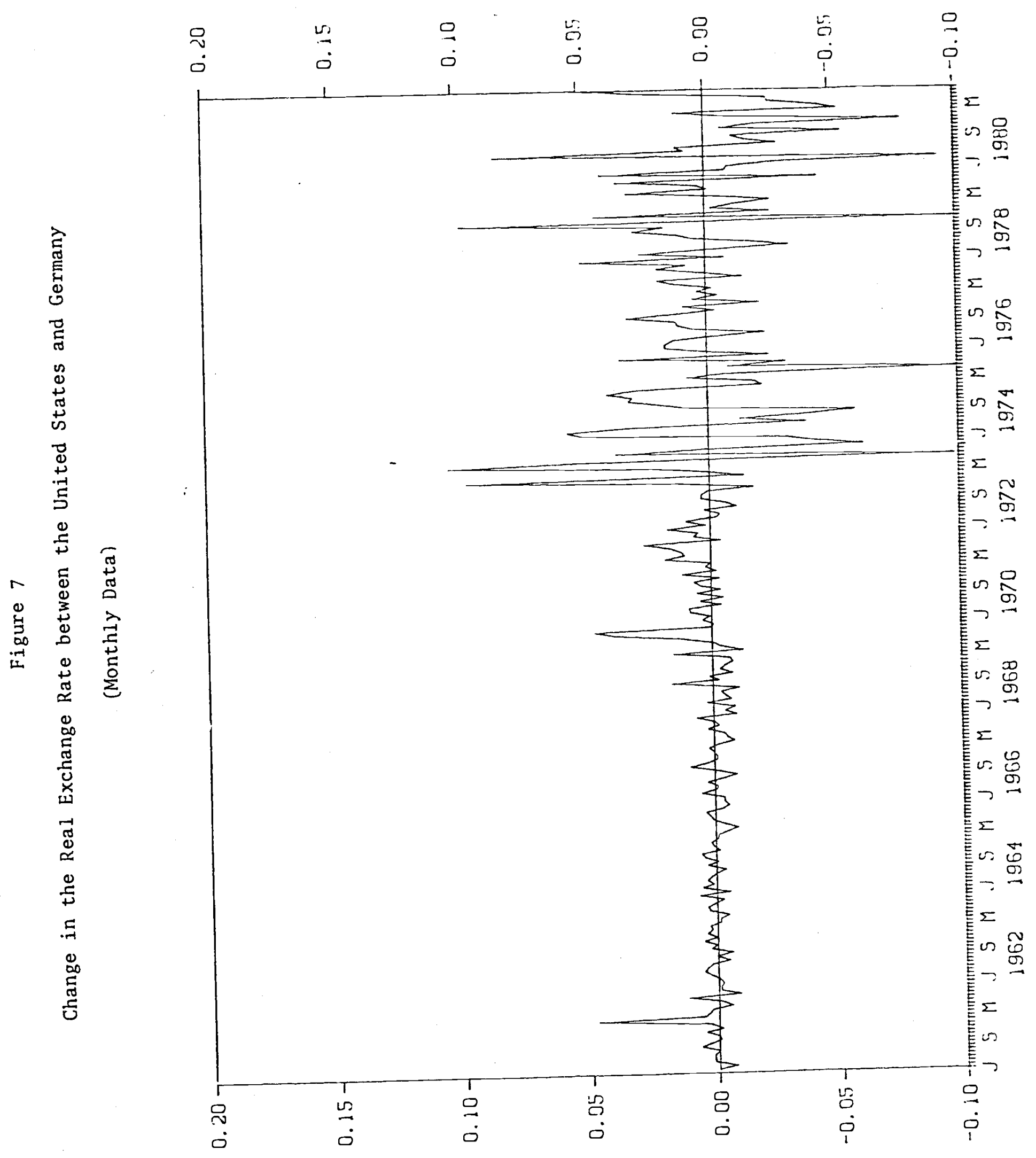




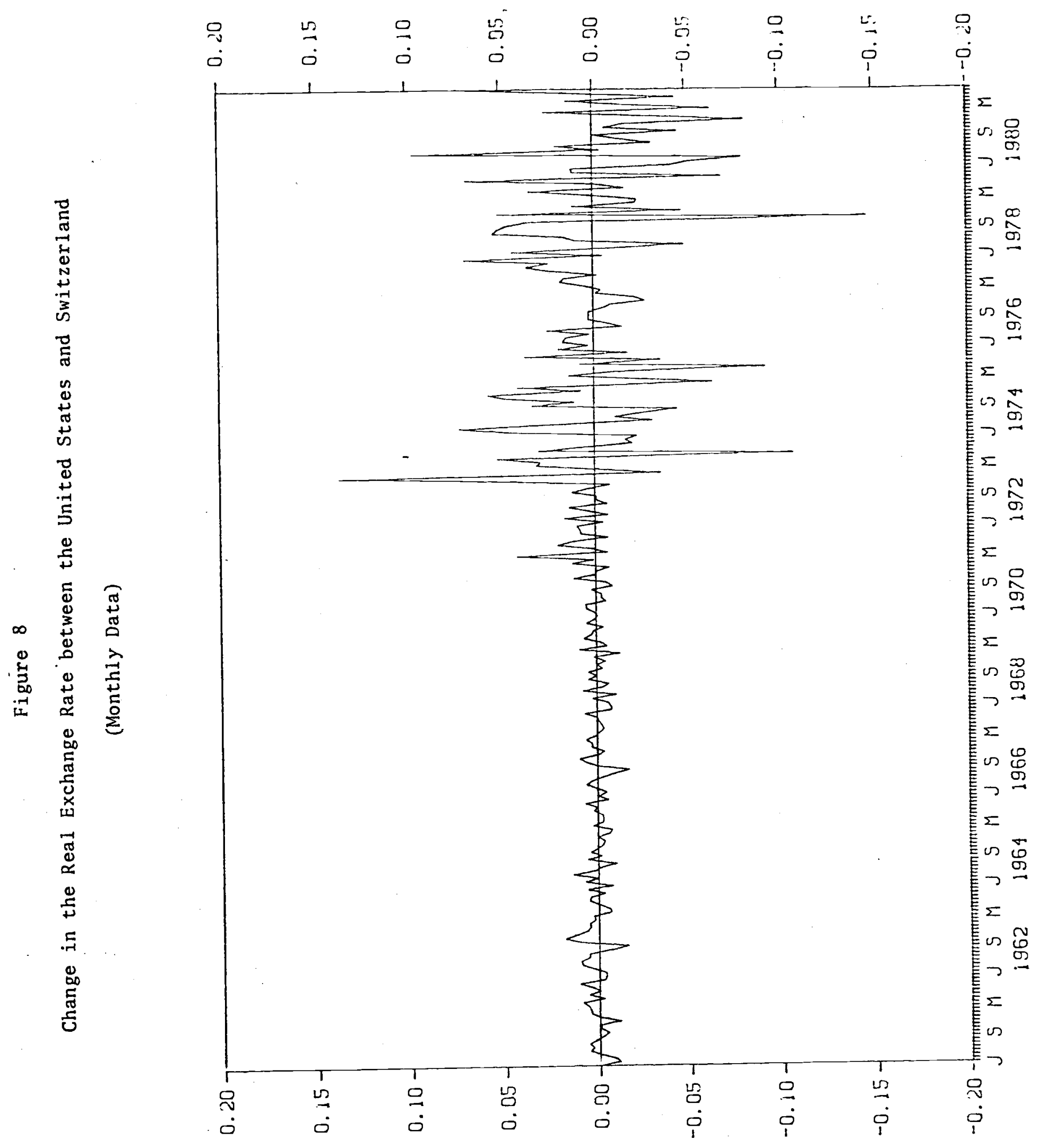


Cumby-Obstfeld

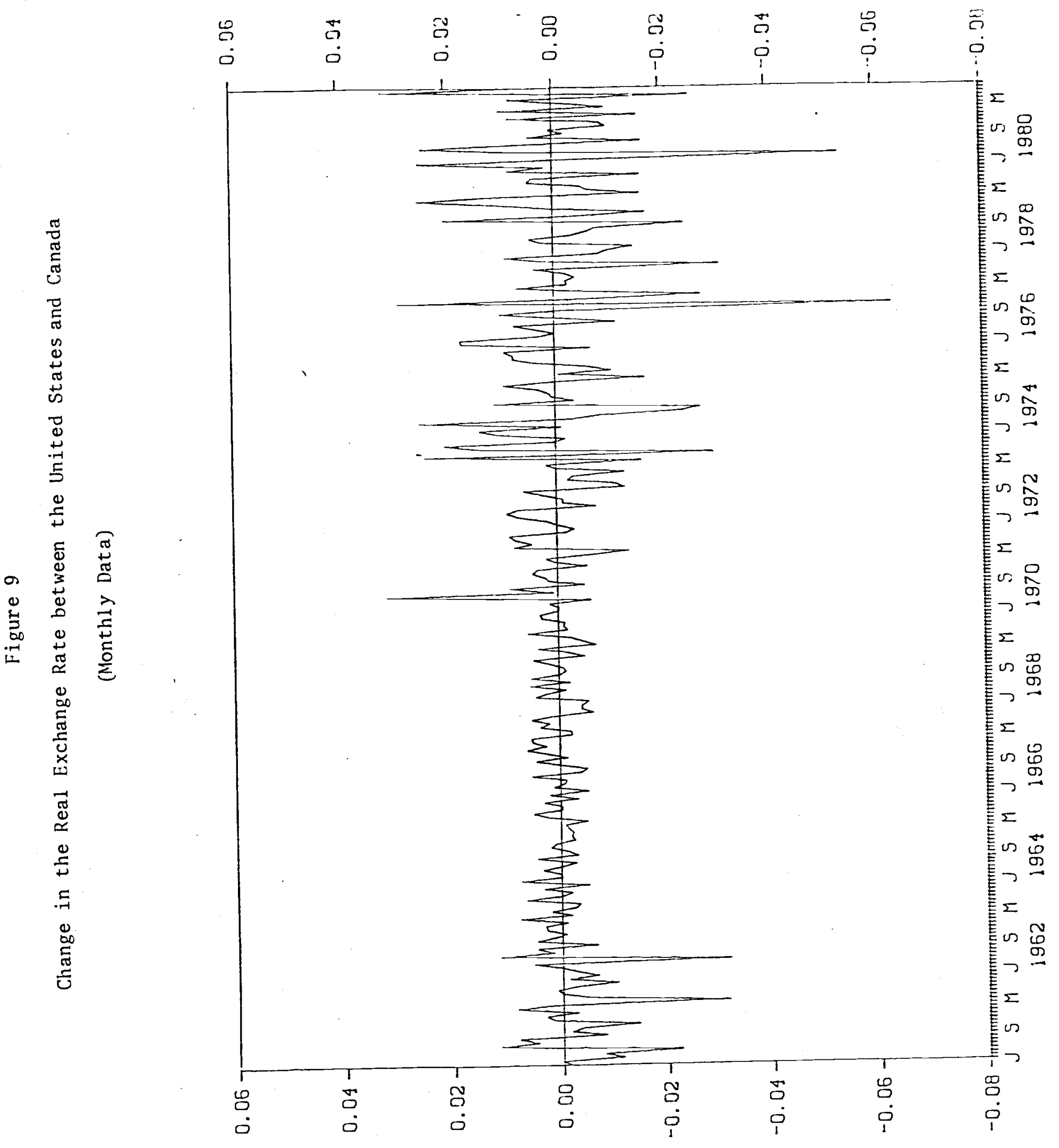


Cumby-Obstfeld

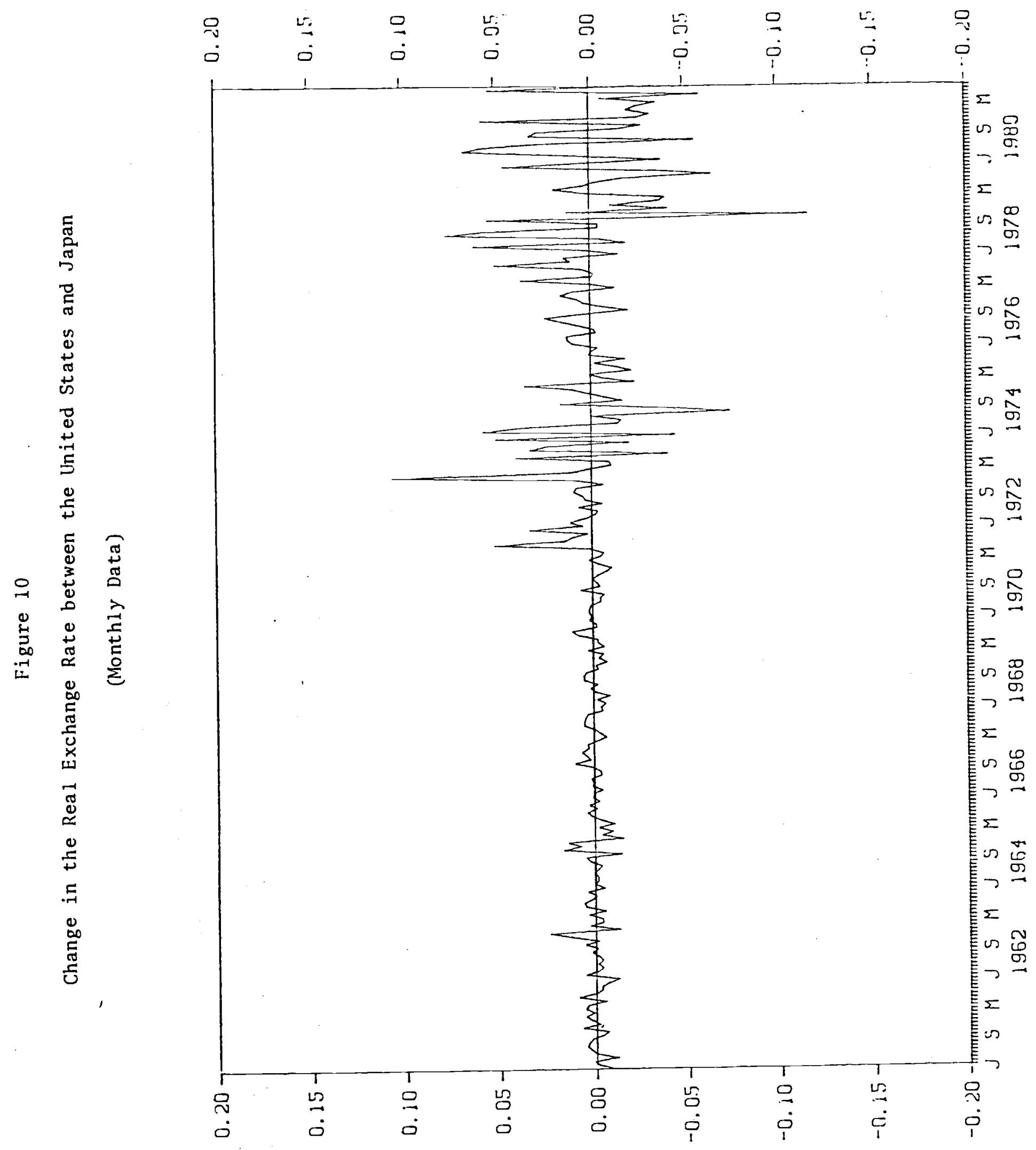




$$
\pi_{t+k}-\pi_{t+k}^{*}=E_{t}\left[\ln \left(S_{t+k} / S_{t}\right)\right]+u_{t+k}-u_{t+k}^{*}
$$

If $E_{t}\left[\ln \left(S_{t+k} / S_{t}\right)\right]$ were observable, a test of whether $a=0$ and $b=1$ in the equation

$$
\pi_{t+k}-\pi_{t+k}^{*}=a+b E_{t}\left[\ln \left(S_{t+k} / S_{t}\right)\right]+e_{t+k}
$$

would be a test of ex ante relative PPP. Because the regressor in (24) is not observable, however, we must find a proxy variable. One possibility, following McCallum (1976), is to use the realized depreciation $\ln \left(\mathrm{S}_{t+k} / \mathrm{S}_{t}\right)$ as a proxy. With this substitution, (24) becomes

$$
\pi_{t+k}-\pi_{t+k}^{*}=a+b \ln \left(S_{t+k} / S_{t}\right)+e_{t+k}-b v_{t+k}
$$

where $v_{t+k}=\ln \left(S_{t+k} / S_{t}\right)-E_{t}\left[\ln \left(S_{t+k} / S_{t}\right)\right]$. Because the independent variable in (25) is correlated with the composite disturbance $e_{t+k}-b v_{t+k}$, OLS is an inconsistent estimation procedure here. But an instrumental-variables estimator such as 2S2SLS can be used to estimate $[a b]^{\prime}$ consistently. Since $e_{t+k}$ and $v_{t+k}$ are rational forecast errors, any relevant variables in the time-t information set may be used as instrumental variables.

\section{Empirical Results}

Results of estimating (25) over a one-month forecasting horizon with monthly data are reported in Table $6 . \frac{23 /}{}$ As in the previous tests, a heteroskedasticity consistent covariance matrix estimator was employed. Tests of 
TABLE 6

Tests of Ex Ante PPP

(September 1975 - May 1981)

\section{Countries}

U.S./U.K.

U.S. /U.K.

U.S./Germany

U.S. / Germany

U.S./Switzerland

U.S./Switzerland WPI

U.S. / Canada

U. S. / Canada

U.S. / Japan

U.S./Japan
Price Index

CPI

WPI

CPI

WPI

CPI

CPI

WPI

CPI

WPI $\hat{a}$

$-.0033$

(.0010)

.1660

(.1205)

$-.0048$

$-.1763$

(.0012)

(.3415)

.0033

(.0006)

.1902

(.0789)

.0034
$(.0009)$

$-.1707$

(.1218)

$\begin{array}{ll}.0037 & .1174 \\ (.0007) & (.1111)\end{array}$

$\begin{array}{ll}.0073 & -.2333 \\ (.0018) & (.2255)\end{array}$

$-.0003$

$(.0005)$

.0822

(.1395)

$-.0002$

(.0007)

.1984

(.1786)

$.0007 \quad .1523$

$(.0012)$

(.1848)

.0037

(.0008)

.0330

(.0725)
Test Statistic

$48.32 * \star$

$17.07 * *$

$166.21 * *$

$94.25^{* \star}$

$63.98 * *$

$29.94 * *$

$65.13^{* x}$

$26.87 * *$

$21.46^{* *}$

$180.79 * *$

Note: Standard errors appear in parentheses. The test statistic is distributed asymptotically as $\chi^{2}(2) . \quad *=$ rejection at the 5 percent level; $* *=$ rejection at the 1 percent level. 
the null hypothesis for a three-month forecasting horizon were also performed, but these are not reported as they only reinforce the message of Table 6.

That message is that expected exchange rate changes have been poor and biased predictors of relative inflation rates over the years of generalized floating. The hypothesis $a=0$ and $b=1$ is decisively rejected for all countries, regardless of the price index used. Further, the estimated slope coefficients are almost always insignificant and frequently of the wrong sign. The one exception to this occurs in the case of the dollarDeutschemark rate, where we find that the expected depreciation rate does help forecast the U.S.-German CPI inflation differential.

Table 7 uses the adjusted $Q$ statistic of Ljung and Box (1978) to test whether real exchange rate changes have been serially uncorrelated in recent years. The test statistics, which are computed for twelve lags using monthly data, confirm the Roll-Frenkel finding that real exchange rate changes are not serially correlated. Only in the Canadian case can the null hypothesis of no serial correlation be rejected at better than the 20 percent significance level. While the foregoing evidence is supportive of ex ante relative PPP, the results of Table 6 are strongly at variance with that hypothesis. On balance, it seems reasonable to conclude that the "efficient markets" version of relative PPP has not characterized the recent experience with floating rates. 
TABLE 7

Tests for Serial Correlation of Real Exchange Rate Changes

(September 1975 - May 1981)

\begin{tabular}{|c|c|c|c|c|c|}
\hline Countries & Price Index & Test Statistic & Marginal & Significance & Leve1 \\
\hline U.S./U.K. & $\mathrm{CPI}$ & 7.79 & & .80 & \\
\hline U.S./U.K. & WPI & 10.63 & & .56 & \\
\hline U.S./Germany & $\mathrm{CPI}$ & 7.09 & & .85 & \\
\hline U.S./Germany & WPI & 7.73 & & .81 & \\
\hline U.S./Switzerland & $\mathrm{CPI}$ & 4.30 & & .98 & \\
\hline U.S. / Switzerland & WPI & 5.00 & & .96 & \\
\hline U.S./Canada & $\mathrm{CPI}$ & 17.62 & & .13 & \\
\hline U.S./Canada & WPI & 16.11 & & .19 & \\
\hline U.S./Japan & $\mathrm{CPI}$ & 11.88 & & .46 & \\
\hline U.S./Japan & WPI & 8.08 & & .78 & \\
\hline
\end{tabular}

Note: The test statistic is distributed asymptotically as $x^{2}(12)$. 
Conclusion

This paper has studied the interplay among price levels, interest rates, and exchange rates over the recent period of managed exchangerate flexibility. Attention was focused on the two classical parity conditions that link prices and nominal interest rates internationally and on their corollary, the international equality of ex ante real rates of interest. Econometric tests of these propositions within a rational-expectations framework provided significant evidence against them. As a by-product of the investigation, we found that inflation and exchangerate forecast errors appear to be conditionally heteroskedastic.

When monetary disturbances are dominant, the classical parity relationships may be a reliable guide to the comovements of nominal macro-variables. But the past decade has been characterized by moderate inflation coupled with substantial real disturbances. In such circumstances, the classical conditions appear to be too simple and aggregative to provide an adequate explanation of macroeconomic events in a world of differentiated commodities and assets.

Whether the failure of the parity relations has conferred monetary autonomy on small open economies is an entirely distinct question. Further theoretical and empirical research is needed before a confident answer can be ventured. 
Appendix: The Data

\section{Section II}

Prices: WPI's are taken from International Financial Statistics (IFS), line 63. CPI's come from IFS, line 64.

Interest Rates: One- and three-month Eurocurrency deposit rates come from Data Resources, Inc. (for the U.K., Germany, and Switzerland) and from the Harris Bank of Chicago Weekly Review (for Canada and Japan). Three-month domestic money-market rates come from Morgan Guaranty's World Financial Markets, and are quoted at or near the end of the month. For the U.S., the rate on prime industrial paper is used. Interbank deposit rates are used for the U.K., Germany, and Switzerland. For Canada, the rate used is that on prime finance company paper. The interest rate on three-month repurchase agreements is used as the Japanese money-market rate.

\section{Section III}

Spot and ninety-day forward exchange rates are noon rates collected by the Federal Reserve System. Spot rates are matched to the maturity of the corresponding forward contract, as described by Riehl and Rodriguez (1977). Morgan Guranty's World Calendar of Holidays is used to account for bank holidays, weekends, etc.

Section IV

Prices: Same as Section II.

Exchange Rates: End-of-month rates taken from IFS, line ag. 


\section{Footnotes}

* We thank J. Frenkel, R. Hodrick, B. Loopesko, R. Meese, and F. Mishkin for helpful comments and discussions. Assistance from N. Killefer and J. Withers is acknowledged with thanks. Obstfeld's research was supported in part by a grant from the National Science Foundation.

1. Examples include Bilson (1979), Frankel (1979a), Frenkel (1976), Hodrick (1978), and Hooper and Morton (1982).

2. In these circumstances, monetary policy also loses its power to systematically influence the terms of trade or real exchange rate, and a second avenue of demand management is thus closed. Even so, monetary policy can be effective if nominal wages are sticky (see Obstfeld (1982a)). But this possibility disappears as well when wages are fully and instantaneously indexed to the aggregate price level. While monetary policy may be ineffective, tax policy can always succeed in driving a wedge between home and foreign ex ante real rates. The discussion below abstracts from taxes. Also ignored is the possibility that changes in monetary growth rates might influence the terms of trade through real effects of the Tobin-Sidrauski sort.

3. If there are no default risks, covered interest arbitrage is riskless (in home currency terms), and so covered interest parity must always hold exactly in the absence of transaction costs. In contrast, lincovered arbitrage involves home-currency risk in an essential way. The relation between covered and uncovered interest parity is discussed in Section III, be low. 
4. This test is suggested by Hodrick (1979). However, he uses the k-period forward premium rather than the k-period nominal interest differential on the right-hand side of (8). The two procedures should yield very similar results when Eurocurrency interest rates are being compared (see Section III).

5. The reason is that the latter uses more information. As noted in the next paragraph of the text, OLS is a special "just-identified" case of this type of instrumental-variables estimator.

6. When the forecast horizon $k$ exceeds one period, $e_{t+k}$ is serially correlated and, under the null hypothesis, has the covariance matrix of a moving average (MA) process. As Hansen and Hodrick (1980) note, two-step serial correlation corrections of the generalized least squares type are inconsistent, even though OLS is consistent. The inconsistency is due to the fact that the nominal interest differential is not a strictly exogenous variable. To see this, suppose that $k=$ 3, so that the hypothesis involves three-month interest rates observed month-

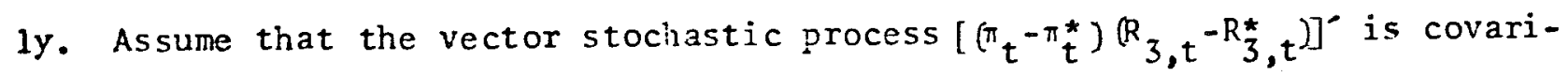
ance stationary and has the indeterministic bivariate wold representation

$$
\begin{aligned}
& \pi_{t}-\pi_{t}^{*}=\sum_{i=1}^{\infty} \psi_{i} \nu_{t-i}+\sum_{i=1}^{\infty} \theta_{i} \omega_{t-i}+\nu_{t}, \\
& R_{3, t}-R_{3, t}^{\star}=\sum_{i=1}^{\infty} \rho_{i} \nu_{t-i}+\sum_{i=1}^{\infty} \delta_{i} \omega_{t-i}+\omega_{t},
\end{aligned}
$$

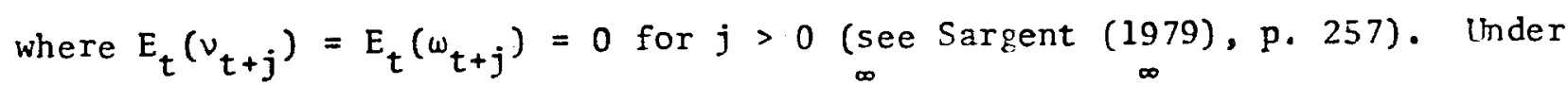
the null hypothesis, $E_{t}\left(\pi_{t+3}-\pi_{t+3}^{*}\right)=\sum_{i=0}^{\infty} \psi_{i+3} \nu_{t-i}+\sum_{i=0}^{\infty} \theta i+3^{\omega} \omega_{t-i}=R_{3, t}-R_{3, t}^{*}$ $=\sum_{i=1}^{\infty} \rho_{i} \nu_{t-i}+\sum_{i=1}^{\infty} \delta_{i} \omega_{t-i}+\omega_{t}$. Thus, if ex ante real interest rates are equal, $\psi_{3}=0, \theta_{3}=1, \rho_{i}=\psi_{i+3}$ and $\delta_{i}=\theta_{i+3}$. This implies that $\pi_{t+3}-\pi_{t+3}^{*}-R_{3, t}$ 
$+R_{3, t}^{*}=v_{t+3}+\psi_{1} v_{t+2}+\psi_{2} v_{t+1}+\theta_{1} \omega_{t+2}+\theta_{2} \omega_{t+1}=e_{t+3}$. Now $e_{t+3}$ has the covariance matrix of an MA process and, by Granger's lemma (see Ansley, Spivey, and Wrobleski (1977)), can be written as an invertible second-order MA process, $e_{t+3}=\zeta_{t+3}+\lambda_{1} \zeta_{t+2}+\lambda_{2} \zeta_{t+1}$. But even though $e_{t+3}$ is uncorrelated with the regressors in $(8), \zeta_{t+3}$ need not be; and therefore apnlication of a generalized-least-squares transformation to (8) will generally induce a nonzero correlation between the filtered disturbance $\zeta_{t+3}$ and the filtered regressors. For a more detailed argument, see Cumby, Huizinga, and Obstfeld (1982). Hansen and Hodrick (1980) use the Wold theorem to provide a similar characterization of the form of the forward exchange rate forecast error when contract periods overlap in the data.

7. See Dhrymes (1974), pp. 183-4. A more recent discussion of the failure of assumption $(10)$ in regression models with i.n.i.d. residuals appears in. White (1980). For time series models, see Engle (1982) and Hansen (1982). It is important to note that even if (10) does not hold, the estimator given in (11) still yields consistent (but relatively inefficient) estimates of parameters.

8. The condition would also be valid if the instmumts and disturbances were jointly normally distributed. Without the joint normality assumption, however, lack of correlation need not imply statistical independence.

9. One can of course obtain more efficient covariance matrix estimates by imposing such information if it is known. Cumby, Huizinga, and Obstfeld (1982) describe one way of doing this. Their method is implemented in obtaining the empirical results reported in this paper. White (1980) has proposed a 
heteroskedasticity-consistent covariance matrix estimator in a cross-sectional context, along with a test of homoskedasticity. White's test is discussed further below.

10. Any product of instrumental variables is a legitimate regressor in (15), but we have excluded all but two in the a priori belief that the others are less likely to be significant in explaining $e_{t+k}^{2}$. It is worth emphasizing that the possibility of conditional heteroskedasticity does not contradict the assumption that $e_{t+k}$ follows a covariance-stationary process. The latter assumption requires only that the unconditional variance of $e_{t+k}$ be constant over time.

11. In order to distinguish empirically between inflation risk and default risk, studies of U.S. real interest rates focus on U.S. treasury bills, which yield a riskless nominal return (Fama 1975, Mishkin 1981, Shiller 1980). As Mishkin (1982) observes, cross-country comparisons of real interest rates are most informative when the bonds being compared have the same default and political risk characteristics. This is true of Eurocurrency deposits denominated in different currencies, but not of onshore bonds traded in different/financial centers. Thus, tests of real rate equality using domestic money-market interest rates should be interpreted with caution. Another cause for caution is the fact that the prices entering CPIs and WPIs are not all sampled every month in revising the previous month's index; indeed some prices are observed only once a year (see Fama(1977), Nelson and Schwert (1977), and Shiller (1980)). This means that over short periods, changes in the price indices correspond only imperfectly to actual price-level movements. Because the implied measurement errors are serially correlated, our tests of real interest rate equality are, 
to some extent, biased. It would be of considerable interest to perform these tests on twleve-month interest and inflation rates.

12. The instrumental variables in these regressions were the time-t nominal interest differentials for all countries in the sample and the time-t nominal interest differentials squared. All data are described in the appendix.

13. The instrumental variables in the regressions were the time-t nominal interest differentials for all countries in the sample.

14. Further, any political risks attaching to Eurocurrency deposits are not denomination-specific, and thus should not influence ex ante real interest differentials in the Eurocurrency market (cf. footnote 11, above).

15. Fama (1975) uses the CPI inflation rate in his study of the predictive power of U.S. short-term interest rates.

16. Similar tests have been conducted by Frenkel (1976) (for the German experience of the 1920s), Frankel (1980), and Stockman (1978). Levich (1978, 1979) surveys the early literature in this area.

17. Hansen and Hodrick (1980) make this assumption explicitly. In a later paper, Hansen and Hodrick (1983) allow for conditional heteroskedasticity in testing a forward foreign exchange pricing model. Hsieh (1982) accounts for conditional heteroskedasticity in his tests, and obtains results similar to those reported in Table 5 below. 
18. The instrumental variables were the time-t forward premia and squared forward premia for all countries in the sample.

19. See Meese and Singleton (1982) and Riehl and Rodriguez (1977).

20. The instrumental variables were the time-t forward premia for all countries in the sample.

21. There are two sharp jumps in the German series over the Bretton Woods period. These correspond to the Deutschemark revaluations of 1961 and 1969 . The spike in the U.K. series corresponds to the sterling devaluation of 1967. 22. Genberg (1978) also notes this phenomenon.

23. Instruments were lagged inflation differentials vis-à-vis the U.S. for all countries in the sample. 


\section{References}

Ansley, C.F.; Spivey, W.A.; and Wrobleski, W.J. "On the Structure of Moving Average Processes," Journal of Econometrics 6 (1977): 121-34.

Bilson, J.F.O. "Recent Developments in Monetary Models of Exchange Rate Determination," International Monetary Fund Staff Papers 26 (June 1979) : 201-23.

- "The 'Speculative Efficiency' Hypothesis," Journal of Business 54 (July 1981): 435-52.

Branson, H.H. "Exchange Rate Dynamics and Monetary Policy," in Inflation and Unemployment in Open Economies, edited by A. Lindbeck. Amsterdam: North-Holland, 1979.

Cumby, R.E. and Obstfeld, M. "A Note on Exchange-Rate Expectations and Nominal Interest Differentials: A Test of the Fisher Hypothesis," Journal of Finance 36 (June 1981): 697-704.

Cumby, R.E.; Huizinga, J.; and Obstfeld, M. "Two-Step Two-Stage Least Squares Estimation in Models with Rational Expectations," Journal of Econometrics, 1982, forthcoming.

Dhrymes, P.J. Econometrics: Statistical Foundations and Apnlications. New York: Springer-Verlag, 1974.

Dornbusch, R. "Expectations and Exchange Rate Dynamics," Journal of Political Economy 84 (December 1976): 1161-76.

- "Monetary Policy under Exchange Rate Flexibility," in Managed ExchangeRate Flexibility: The Recent Experience. Federal Reserve Bank of Boston Conference Series no. 20. Boston: Federal Reserve Bank of Boston, 1978. - "Exchange Rate Economics: Where Do We Stand?" Brookings Papers on Economic Activity 11 (1980): 143-85. 
Engle, R.F. "Autoregressive Conditional Heteroscedasticity with Estimates of the Variance of United Kingdom Inflation," Econometrica 50, 1982, forthcoming.

Fama, E.F. "Short-Term Interest Rates as Predictors of Inflation," American Economic Review 65 (June 1975): 269-82.

- "Interest Rates and Inflation: The Message in the Entrails," American Economic Review 67 (June 1977): 487-96.

Fisher, I. The Theory of Interest. New York: Macmillan, 1930.

Frankel, J.A. "On the Mark: A Theory of Floating Exchange Rates Based on Real Interest Differentials," American Economic Review 69 (September 1979): 610-22.(a)

- "The Diversifiability of Exchange Risk," Journal of International Economics 9 (August 1979): 379-94. (b)

- "Tests of Rational Expectations in the Forward Exchange Market," Southern Economic Journal 46 (April 1980): 1083-1101.

Frenkel, J.A. "A Monetary Approach to the Exchange Rate: Doctrinal Aspects and Empirical Evidence," Scandinavian Journal of Economics 78 (May 1976): $200-24$.

- "Purchasing Power Parity: Doctrinal Perspectives and Evidence from the 1920's," Journal of International Economics 8 (May 1978): 169-91. - "Flexible Exchange Rates, Prices, and the Role of 'News': Lessons from the 1970s," Journal of Political Economy 89 (August 1981): 665-705.

Frenkel, J.A. and Levich, R.M. "Covered Interest Arbitrage: Unexploited Profits?" Journal of Political Economy 83 (April 1975): 325-38.

- "Transaction Costs and Interest Arbitrage: Tranquil versus Turbulent Periods," Journal of Political Economy 85 (December 1977) : 1209-26. 
Frenkel, J.A. and Levich, R.M. "Covered Interest Arbitrage in the 1970's," Economics Letters 8 (1981): 267-74.

Genberg, H. "Purchasing Power Parity under Fixed and Flexible Exchange Rates," Journal of International Economics 8 (May 1978): 247-76.

Geweke, J.F. and Feige, E.L. "Some Joint Tests of the Efficiency of Markets for Forward Foreign Exchange," Review of Economics and Statistics 61 (August 1979): $334-41$.

Girton, L. and Henderson, D.W. "Central Bank Operations in Foreign and Domestic Assets under Fixed and Flexible Exchange Rates," in The Effects of Exchange Rate Adjustments, edited by P.B. Clark, D. Logue, and R. Sweeney. Washington: U.S. Government Printing Office, 1977. Grauer, F.; Litzenberger, R.; and Stehle, R. "Sharing Rules and Enuilibrium in an International Capital Market under Uncertainty," Journal of Financial Economics 3 (June 1976): 233-56.

Hakkio, C.S. "The Term Structure of the Forward Premium," Journal of Monetary Economics 8 (July 1981): 41-58.

Hansen, L.P. "Large Sample Properties of Generalized Method of Moments Esti- mators," Econonetrica 50, 1982, forthcoming.

Hansen, L.P. and R.J. Hodrick. "Forward Exchange Rates as Optimal Predictors of Future Spot Rates: An Econometric Analysis," Journal of Political Economy 88 (October 1980): 829-53.

- "Risk Averse Speculation in the Forward Foreign Exchange Market: An Econometric Analysis of Linear Models," in Exchange Rates and International Macroeconomics, edited by J.A. Frenkel. Chicago: University of Chicago Press for the National Bureau of Economic Research, 1983. Henderson, D.W. "Exchange Market Intervention Operations: Their Effects and Their Role in Financial Policy." This volume. 
Hodrick, R.J. "An Empirical Analysis of the Monetary Approach to the Determination of the Exchange Rate," in The Economics of Exchange Rates, edited by J.A. Frenkel and H.G. Johnson. Reading: Addison-Wesley, 1978.

- "Some Evidence on the Equality of Expected Real Interest Rates Across Countries." Working Paper, Graduate School of Industrial Administration, Carnegie-Melion University, 1979.

- "International Asset Pricing with Time-Varying Risk Promia." Journal of International Economics 11 (November 1981): 57.3-87.

Hooper, P. and Morton, J. "Fluctuations in the Dollar: A Model of Nominal and Real Exchange Rate Determination," Journal of International Money and Finance 1, 1982, forthcoming.

Hsieh, D.A. "Tests of Rational Expectations and No Risk Premium in Forward Exchange Markets." Working Paper no. 843, National Bureau of Economic Research, Cambridge, Mass., 1982.

Keynes, J.M. A Tract on Monetary Reform. London: Macmillan, 1923.

Kouri, P.J.K. "International Investment and Interest Rate Linkages under Flexible Exchange Rates," in The Political Economy of Monetary Reform, edited by R.Z. Aliber. London: Macmillan, 1977.

Krasker, W.S. "The 'Peso Problem' in Testing the Efficiency of Forward Exchange Markets," Journal of Monetary Economics 6 (April 1980): 269-76.

Krugman, P.R. "Purchasing Power Parity and Exchange Rates: Another Look at the Evidence," Journal of International Economics 8 (August 1978): $397-407$.

Levich, R.M. "Further Results on the Efficiency of Markets for Foreign Fxchange," in Managed Fxchange-Rate Flexibility: The Recent Experience. Federal Reserve Bank of Boston Conference Series no. 20. Boston: Federal Reserve Bank of Boston, 1978. 
Levich, R.M. "On the Efficiency of Narkets for Foreign Exchange," in International Economic Policy: Theory and Evidence, edited by $R$. Dornbusch and J.A. Frenkel. Baltimore: Johns Hopkins University Press, 1979.

Ljung, C.M. and Box. G.E.P. "On a Measure of Lack of Fit in Time Series Models," Biometrika 65 (1978): 297-303.

Longworth, D. "Testing the Efficiency of the Canadian-U.S. Exchange Market under the Assumption of No Risk Premium," Journal of Finance 36 (March 1981): 43-9.

McCallum, B.T. "Rational Expectations and the Natural Rate Hypothesis: Some Consistent Estimates," Econometrica 44 (January 1976) : 43-52. McCormick, F. "Covered Interest Arbitrage: Unexploited Profits? Comment," Journal of Political Economy 87 (April 1979): 411-17.

Magee, S.P. "Contracting and Spurious Deviations from Purchasing Power Parity," in The Economics of Exchange Rates, edited by J.A. Frenkel and H.G. Johnson. Reading: Addison-Wesley, 1978.

Marston, R.C. "Interest Arbitrage in the Eurocurrency Markets," European Economic Review 7 (January 1976): 1-13.

Meese, R.A. and K.J. Singleton. "A Note on Unit Roots and the Empirical Modeling of Exchange Rates," Journal of Finance 37, 1982, forthcoming. Mishkin, F.S. "The Real Interest Rate: An Empirical Investigation," in The Costs and Consequences of Inflation, edited by $K$. Brunner and A.H. Meltzer. Carnegie-Rochester Conference Series on Public Policy vol. 15 (supplementary series to the Journal of Monetary Economics, 1981).

- "The Real Interest Rate: A Multi-Country Empirical Study." Parts I and II. Working Paper, Department of Economics, University of Chicago, 1982. 
Mussa, M. "Empirical Regularities in the Behavior of Exchange Rates and Theories of the Foreign Exchange Market," In Policies for Employment, Prices, and Exchange Rates, edited by K. Brunner and A.H. Meltzer. Carnegie-Rochester Conference Series on Public Policy vol. 11 (supplementary series to the Journal of Monetary Economics, 1979).

- "A Model of Exchange Rate Dynamics," Journal of Political Economy 90 (February 1982): 74-104.

Nelson, C.R. and Schwert, G.W. "Short-Term Interest Rates as Predictors of Inflation: On Testing the Hypothesis that the Real Rate of Interest is Constant," American Economic Review 67 (June 1977): $478-86$.

Obstfeld, M. "Relative Prices, Employment, and the Exchange Rate in an Economy with Foresight," Econometrica 50, 1982, forthcoming. (a) - "Can We Sterilize? Theory and Evidence," American Economic Review Papers and Proceedings 72 (May 1982), in press. (b)

Rieh1, H. and Rodriguez, R.M. Foreign Exchange Markets. New York: McGrawHill, 1977.

Roll, R. "Violations of Purchasing Power Parity and Their Implications for Efficient International Commodity Markets," in International Finance and Trade, edited by M. Sarnat and G.P. Szego. Vol. 1. Cambridge: Ballinger, 1979.

Roll, R. and Solnik, B. "On Some Parity Conditions Frequently Encountered in International Economics," Journal of Macroeconomics 1 (1979): 267-83. Sargent, T.J. Macroeconomic Theory. New York: Academic Press, 1979. 
Shiller, R.J. "Can the Fed Control Real Interest Rates?" in Rational Expectations and Economic Policy, edited by S. Fischer. Chicago: University of Chicago Press for the National Bureau of Economic Research, 1980.

Stockman, A.C. "Risk, Information, and Forward Exchange Rates," in The Economics of Exchange Rates, edited by J.A. Frenkel and H.G. Johnson. Reading: Addison-Wesley, 1978.

Stulz, R.M. "A Model of International Asset Pricing," Journal of Financial Economics 9 (December 1981): 383-406.

White, H. "A Heteroskedasticity-Consistent Covariance Matrix Estimator and a Direct Test for Heteroskedasticity," Econometrica 48 (May 1980): $817-38$ 